\title{
The Home Court Advantage in International Corporate Litigation
}

Forthcoming: Journal of Law and Economics

\author{
Utpal Bhattacharya \\ (Indiana University) \\ Neal Galpin \\ (Texas A\&M University) \\ Bruce Haslem \\ (Florida State University)
}

JEL Classification: G14, G15, K40, N20

First version: February 2004

This version: August 2006

*The authors thank Anup Agrawal, Kevin Clermont, Art Durnev, Ray Fisman, Dirk Jenter, Andrew Karolyi, Joshua Lerner, Wendy Liu, Randall Morck, Eric Rasmusen, Roberta Romano, Antoinette Schoar, Mark Seasholes and participants in the seminar at Indiana and at the American Finance Association Meetings (Boston, 2006) for improving the paper. Special thanks go to an anonymous referee. 


\title{
THE HOME COURT ADVANTAGE IN INTERNATIONAL CORPORATE LITIGATION
}

\begin{abstract}
$\underline{\text { Abstract }}$
Using a comprehensive sample of 2,361 public U.S. corporate defendants and 715 public foreign corporate defendants in U.S. federal courts in the period 1995-2000, we find that the market reaction at the announcement of a U.S. federal lawsuit is less negative for U.S. corporate defendants. We find that this market reaction is rational; U.S. firms are less likely to lose than foreign firms controlling for year, industry, type of litigation, size and profitability. This may still reflect a sample selection bias. We control for this bias, and the results remain. We thus cannot rule out that U.S. firms have a home court advantage in U.S. federal courts.
\end{abstract}


THE HOME COURT ADVANTAGE IN INTERNATIONAL CORPORATE

\section{LITIGATION}

\section{Introduction}

The Loewen Corporation, a small Canadian firm that runs a funeral home chain, was sued by Jerry O’Keefe in the state of Mississippi in 1995. It seemed like a routine contract squabble. The value of the enterprises at stake was estimated to be a mere USD 8.5 million. Yet, a percentagefee trial lawyer convinced a Mississippi jury to award USD 100 million and USD 400 million as compensatory and punitive damages respectively. These amounts would have wiped out the small

firm's net worth. A state judge refused to lower or set aside this verdict. The Mississippi Supreme Court asked for a bond of USD 625 million if the case was to be appealed. Loewen Corporation settled for USD 100 million. Its stock crashed from USD 41 to USD 8, and it almost became bankrupt. $^{1}$

The global nature of this case is not unusual. As globalization progresses, cross-border corporate lawsuits, where the plaintiff is from country A and the defendant is from country B, are becoming more frequent. $^{2}$ The large tort award, also, is not unusual. Tort awards are much higher

\footnotetext{
${ }^{1}$ Wall Street Journal, February 14, 1996. We thank Randall Morck for bringing this case to our attention.

${ }^{2}$ The most recent example of interesting issues being raised by cross-border litigation was the recent U.S. Supreme Court decision to take up the case of whether foreign regulators can ask U.S. firms for confidential business information (Wall Street Journal, November 11, 2003)
} 
in the U.S. than in other countries. ${ }^{3}$ The presence of a percentage-fee trial lawyer in this international case, also, is not unusual. U.S. trial lawyers are globalizing their industry. ${ }^{4}$ What is unusual in this case is the crude appeal to patriotism that the plaintiff's lawyers made. Walter Olson, covering this case for the Wall Street Journal of February 14, 1996, in an article titled "A Small Canadian Firm Meets the American Tort Monster,” analyzed the strategies of Mr. O’ Keefe's lawyer. The 'dump on outsiders' strategy was particularly effective. It was mentioned in the closing arguments that Mr. O’Keefe "fought for his country" and was now willing to "stand up for America” by suing this rich, foreign company.

We have two goals in this paper. First, and foremost, we want to bring methodologies from financial economics to address whether foreign firms have a disadvantage in U.S. courts or, to put it another way, whether U.S. firms have a home court advantage in their own country's courts. Second, if there is a home court advantage, we want to explore whether a jury or judge bias exists.

The possibility of a home court bias is an important legal and economic concern. It is an important legal concern because, if we find that U.S. firms have an advantage in U.S. federal courts vis a vis foreign firms, it raises basic issues of equity before the law. It is an important economic

${ }^{3}$ The most comprehensive estimates of tort liability direct costs come from a consulting firm, Tillinghast-Towers Perrin. Their 2003 report estimates a tort cost of \$233 billion in the U.S. in 2002 (2.23\% of U.S. GDP). This has increased more than hundredfold from \$1.8 billion in 1950 (0.61\% of U.S. GDP). In Italy and Germany, the next two closest countries in terms of tort costs, tort costs were $1.7 \%$ and $1.3 \%$ of GDP respectively in 2000 (page 20, The Economics of U.S. Tort Liability: A Primer, October 2003.)

${ }^{4}$ An article on litigation risk in the Economist (January 8, 2004), titled “All American Now?” argues that, as the Sarbanes-Oxley Act of 2002 illustrates, foreign firms in the U.S. are losing much of their exemption from U.S. corporate law. This gives an opportunity to American trial lawyers to globalize their industry and bring lawsuits against foreign firms in U.S. courts. As a matter of fact, trial lawyers were touring Europe to drum up interest among European institutional shareholders in 2003. 
concern because, if we find that U.S. firms have an advantage in U.S. federal courts vis a vis foreign firms, it is a disincentive to foreign firms wishing to expand their business in the U.S. As a matter of fact, if local firms everywhere have a home court advantage in their local courts, it is an obstacle to globalization. The notion that a home court advantage is an impediment to globalization is an unexplored hypothesis, but the exploration of this hypothesis is beyond the scope of this paper.

The first part of our paper documents that there is an abnormal share price drop for the defendant firm in its home market at the announcement of litigation. The percentage of market value lost, however, is less for the U.S. corporate defendant than it is for the foreign corporate defendant. The difference is economically and statistically significant.

The finding that the market considers litigation to be bad news for the defendant is not new - see, for example, papers by Cutler and Summers (1987), Engelman and Cornell (1988), Bhagat, Brickley and Coles (1994), Bizjak and Coles (1995), Bhagat, Bizjak and Coles (1998) and Karpoff and Lott $(1993,1999)$. However, as our sample size is in the order of thousands, compared to the sample size of the order of tens or hundreds in previous papers, our contribution in this aspect should be considered as a robustness check of previous findings. The second finding - litigation is regarded as less bad news for U.S. firms than it is for foreign firms - is, to the best of our knowledge, new.

The second part of our paper explores reasons why shareholders react less negatively when a U.S. firm is sued than when a foreign firm is sued. Assuming that the sample of U.S. defendant firms is similar to the sample of foreign defendant firms - an assumption we rigorously put to the test throughout the paper - one reason that litigation could be considered less bad news for U.S. defendant firms than it is for foreign defendant firms is that U.S. defendant firms have the cases against them dismissed more often and/or U.S. defendant firms lose less often than foreign defendant 
firms in U.S. federal courts. We document that, controlling for year, industry, type of litigation, size and profitability, dismissal rates for U.S. defendant firms are not reliably different from dismissal rates for foreign defendant firms, but, if the case goes to trial, U.S. defendant firms are less likely to lose a U.S. federal lawsuit than a foreign firm.

If U.S. firms are less likely to lose, should they settle less often? The literature does not give an unambiguous answer. ${ }^{5}$ We follow the methodology laid out by Perloff, Rubinfeld and Rudd (1996) to estimate settlement probabilities. This methodology takes into account that, as litigants are forward looking, settlement probabilities are a function of win/loss probabilities. We find that the settlement rates of U.S. defendant firms and foreign defendant firms are indistinguishable.

Interpretations from win/loss rates in litigation are problematic because the sample of firms that go to trial is endogenous. Priest and Klein (1984) is the classic paper that describes one particular type of self-selection bias: cases going to litigation are not a random sample, but actually are cases that could not be settled. ${ }^{6}$ The Perloff, Rubinfeld and Rudd (1996) methodology mentioned above addresses this particular sample selection problem. The other sample selection

${ }^{5} \mathrm{~A}$ lucid exposition of the litigate vs settle question is given in Posner (1998, Chapter 21). See references therein for more advanced studies.

${ }^{6}$ Priest and Klein (1984) first argued that cases in which the outcome is clear - the defendant has a strong case or the defendant has a weak case - are likely to be settled, whereas the cases that go to trial have outcomes that are unclear. This means that each litigant is likely to win about $50 \%$ of the time. This paper spawned a large literature. We discuss a few papers. Eisenberg (1990) empirically rejected the $50 \%$ result. Shavell (1996) showed that the $50 \%$ win rate result is an artifact of symmetric information; any win rate is possible under asymmetric information. Wittman (1985) and Hylton (1993) presented models where the 50\% win rate prediction did not hold. Waldfogel (1995) made the point that the $50 \%$ win rate prediction was not the only prediction of the PriestKlein (1984) model, and he tested some of the other predictions. He also structurally estimated the model for different case types. Siegelman and Waldfogel (1999) find that the Priest-Klein (1984) model fits the data when one more parameter is introduced: plaintiffs face greater uncertainty than defendants. 
problem is more basic: lawsuits are not a random sample, but actually are instances where plaintiffs believe that their benefits from suing outweigh their costs. This particular type of sample selection bias in our case manifests itself in the following way: as it is more difficult to collect from foreign firms and as the cost of bringing a lawsuit against a foreign firm is higher, the hurdle rate for lawsuits is higher for foreign firms than it is for U.S. firms. This implies that the sample of foreign defendant firms, as opposed to the sample of U.S. defendant firms, are firms where the claimed damages and/or the ex-ante probability of a defendant loss is higher. This sample selection bias explains why foreign defendant firms lose more than U.S. defendant firms, and why shareholders react more negatively when a foreign firm is sued than when a U.S. firm is sued.

We devise five tests to control for this second type of sample selection bias. One of these tests had been mentioned before. Our multi-variate tests had controls for year, industry, type of litigation, size and profitability, and this had mitigated some sample selection bias. Second, the law and economics literature (see, Posner (1998), page 610) predicts that in a world of symmetric information, everything else equal, the higher the stakes in a case, the more likely it is to be litigated. The intuition is that if the stakes are small, the potential gains from litigating tend to be dominated by the costs of litigating. This means that if the damages claimed against U.S. firms are lower than the damages claimed against foreign firms, we should see lower litigation rates and higher settlement rates for U.S. firms, everything else equal. As we mentioned before, we do not find this.

Our third test is direct. We control for sample selection bias using the methodology laid out by Heckman (1979). To do this, we increase our sample to include firms, both U.S. and foreign, that were not sued in the 1995 to 2000 period. This allows us to do the first step of the Heckman (1979) method - estimate the probability of being sued - and we then use this estimate in the second step 
of the Heckman (1979) method - estimate the "corrected" probability of a win. We find that our results remain: controlling for year, industry, type of litigation, size and profitability, U.S. defendant firms are less likely to lose a U.S. federal lawsuit than a foreign firm.

The fourth group of tests to check for sample bias comes from international finance. There is mounting evidence that foreign firms which have their American Depositary Receipts (ADRs) on U.S. exchanges "rent” U.S. laws. ${ }^{7}$ This implies that, everything else the same, it is easier to collect from foreign firms with ADRs than from foreign firms without ADRs. Therefore, if this particular selection bias is true, foreign defendant firms with ADRs should have less negative market reaction, should have the cases against them dismissed more often, and, if the case does go to trial, should lose less often than a sample of foreign defendant firms without ADRs. We find no evidence of this.

Finally, for our fifth set of tests, we try to obtain information on damages awarded. This information is available only for a subset of our sample. We find that the median damage award is higher for U.S. firms than for foreign firms, but the mean damage award is lower for U.S. firms than for foreign firms. However, the difference in medians or means is not statistically significant.

We thus cannot rule out that U.S. firms have a home court advantage in U.S. federal courts. Moore (2003) meticulously cites various sources to show that there is widespread perception that American courts are hostile to foreign parties. She makes the point that the grant of alienage jurisdiction to federal courts is an explicit recognition of the potential for anti-foreigner bias in state

${ }^{7}$ An American Depositary Receipt (ADR) is a negotiable certificate issued by a U.S. bank representing a specified number of shares (or one share) in a foreign stock. This certificate is traded on a U.S. exchange or U.S. over-the-counter (OTC) market. ADRs are denominated in U.S. dollars, with the underlying security held by a U.S. financial institution overseas. ADRs are an excellent way to buy shares in a foreign company while realizing any dividends and capital gains in U.S. dollars. ADRs are listed on either the NYSE, AMEX, Nasdaq or OTC markets. ADRs are subject to the same rules and regulations of these exchanges that domestic U.S. stocks conform to. 
courts. But do the facts match the perception? Clermont and Eisenberg (1996) found from a sample of diversity and alienage civil cases in federal courts, 1986 through 1994, that foreigners win a higher proportion of cases than do domestic parties. Moore (2003), in a study of only patent infringement cases occurring from 1999 to 2000, finds results that are opposite to Clermont and Eisenberg (1996).

Our paper supports the conclusion of Moore (2003): foreign firms are disadvantaged in U.S. courts. The methodologies used in our two papers are different. Moore (2003) focuses on the number of patent infringement cases scaled by the total number of patents awarded. This mitigates a serious sample selection problem: the impossibility of determining the number of situations that could have led to a lawsuit. We, on the other hand, investigate all the popular types of litigation in U.S. federal courts, and use a number of methods to mitigate another serious sample selection issue: the lawsuits against foreign firms could be more serious. Though our paper supports Moore (2003) in the finding that foreign firms are disadvantaged in U.S. courts, it does not support her finding that this is because of jury bias. We, on the other hand, find that the bias is in judge trials, not jury trials. Our papers should be considered complementary.

The paper is organized as follows. Section 2 discusses our data set. Section 3 analyzes the different market reactions at the announcement of litigation for U.S. corporate defendants vis a vis foreign corporate defendants. It finds that markets react less negatively in the case of U.S. defendant firms. Section 4 explores the reasons behind the different market reactions. It finds that dismissal rates and settlement rates for U.S. defendant firms are not reliably different from dismissal rates and settlement rates respectively of foreign defendant firms. However, if the case goes to trial, U.S. defendant firms are less likely to lose than a foreign firm. Section 5 explores whether sample 
selection biases can explain why foreign defendant firms lose more than U.S. defendant firms. It finds that the results remain after the sample selection bias is controlled. We, therefore, cannot rule out the hypothesis that U.S. firms have a home court advantage in U.S. federal courts vis a vis foreign firms. Section 6 tentatively explores the reasons why U.S. firms have a home court advantage in U.S. federal courts. Section 7 summarizes the results.

\section{Data}

The events used in this study were gathered from PACER, which is a database of cases filed in the United States federal courts. An advantage of using the PACER database over newspaper sources to identify corporate lawsuits is that, since PACER contains all cases that were filed in U.S. federal courts, our sample does not suffer from media bias. A disadvantage of using the PACER database is that only the first named defendant is listed on the index. This means that we would have passed over many cases where the first defendant was not a publicly listed firm but the other defendants were. Despite this shortcoming, there is no reason to expect these biases to differentially affect the sub-sample of U.S. corporate defendants and foreign corporate defendants.

We chose cases filed between 1995 and 2000, so that there was a good chance of them being resolved by the year 2003 for the tests in this paper. We searched by the following popular types of violations: antitrust, breach of contract, employment-related, patent infringement and product liability. ${ }^{8}$ We narrowed our search to only publicly listed defendant firms. We obtained 12,646

${ }^{8}$ The other popular violation is shareholder lawsuits. We did not consider shareholder lawsuits because they were almost always class-action lawsuits, which, among other idiosyncracies, have multiple filing dates. Also, for antitrust cases, we removed all cases where the U.S. government was the plaintiff. This is because Haslem (2005) documented that the U.S. government always wins in antitrust cases in our 1995-2000 sample. 
cases. Second, to keep the event window untainted, we removed all cases that had a previous filing within the last nine months. This left us with 3,851 cases. Third, we screened out all cases for which we did not have stock return data. This gave us 3,076 cases, of which 2,361 involved U.S. defendant firms and 715 involved foreign defendant firms. It is interesting to note that of all lawsuits filed against public firms in U.S. federal courts in our final sample, 29\% are against foreign firms in 2000. This has steadily increased from $20 \%$ in 1995 . To the best of our knowledge, this particular impediment to globalization has escaped academic or popular attention.

We then downloaded information for each case in our sample. Typically, the information gathered from the courts would include the filing date, the date the case was closed, and any motions or judgments entered into the court documents. The information would also include how the case was resolved, or why it was removed from the court's docket. We can classify case outcomes into four general groups: cases dismissed by the judge, cases resolved with a summary judgment by a judge, cases resolved in formal trial, and settlement. This allows us to calculate dismissal rates, which is the number of cases dismissed by the judge divided by all cases for which we know the outcome. The settlement rate is the number of cases settled divided by all cases for which we know the outcome. The win (loss) rate is the number of cases in which a judge or jury rules in favor of the defendant (plaintiff) divided by all cases which were not settled nor dismissed and for which we know the outcome. We also find out whether a jury or a judge decided the case. Panel A in the Appendix, "Definition of variables and data sources," summarizes all the legal variables used in the paper.

Panel B in the Appendix, “Definition of variables and data sources,” summarizes all the firmspecific variables used in the paper. Both U.S. and foreign defendant firms are grouped into ten 
industries, and these industries are classified as in Fama and French. ${ }^{9}$ Sales, assets, profit, free cash flow, leverage, and market to book ratio are directly obtained or computed (formulas given in Panel B in the Appendix) from Compustat for U.S. firms and from Worldscope for foreign firms. The abnormal return for a firm is defined as the actual return minus the expected return. The expected return is obtained from the market model. Data for computing the abnormal return is obtained from CRSP for U.S. firms and from Datastream for foreign firms. Panel C in the Appendix, "Definition of variables and data sources,” gives more details on the computation of abnormal returns. Finally, we have a dummy variable called ADR (American Depository Receipt) associated with foreign firms, which equals 1 if a foreign firm has an ADR listing in the U.S, and is 0 otherwise. This data is obtained from the Bank of New York.

Table 1 gives descriptive statistics on the sample of U.S. corporate defendants and foreign corporate defendants in U.S. federal lawsuits. The objective of Table 1 is to compare and contrast U.S. defendant firms vis a vis foreign defendant firms, and analyze whether the samples are starkly different. It is our first attempt to spot sample selection bias.

\section{INSERT TABLE 1 HERE}

As can be seen from Table 1, the two types of defendants are different. Foreign corporate defendants are bigger, both in terms of sales as well as in size of assets. We, however, find that U.S. corporate defendants seem to have deeper pockets than foreign corporate defendants, whether deep pockets are measured in profitability, free cash flow or valuation (market-to-book ratio). This result in Table 1 is direct evidence against one particular sample selection bias hypothesis: as it is more difficult to collect from foreign firms, we would expect only foreign firms with deep pockets to be

${ }^{9} \mathrm{http} / /$ mba.tuck.dartmouth.edu/ages/faculty/ken.french/Data_Library/det_10_ind_port.html 
sued. Finally, the leverage of U.S. defendant firms are higher, but they are not dangerously higher. The leverage of U.S. defendants (24\%) is similar to the leverage of the median U.S. public firm (which was $28 \%$ in 2000 , and was $24 \%$ in the period 1973 to 2002 ).

Table 1 also gives the number of cases that were dismissed, that were settled, that the defendant won, that the defendant lost, for U.S. firms and for foreign firms. We present these four types of numbers by the nature of the lawsuit (antitrust, breach of contract, employment-related, patent infringement and product liability), by the location of the U.S. federal court (midwest, northeast, south and west), and by industry (non-durables, durables, manufacturing, energy, high tech, telecommunications, retail, health care, and others) ${ }^{10}$. Two points need to be made here. First, there seems to be no significant difference in the type of litigation or the jurisdiction of legislation that U.S. corporate defendants and foreign corporate defendants were involved in the period 1995 through 2000. Second, sorting by nature of lawsuit or by industry leads to very small samples for foreign firms in some types of lawsuits (e.g., breach of contract) or some types of industries (e.g. durables). This imbalance prevents us from doing interaction effects later in the analysis. Interaction effects with court location, however, are possible.

\section{Market reaction at announcement of litigation}

We compute the abnormal return at the announcement of litigation for the two samples using standard event study methodology. Abnormal returns are computed using the market model, with this industry.

${ }^{10}$ We classify the utilities industry as "others" because there were no foreign firms sued in 
each company’s home country index serving as the market proxy. ${ }^{11}$

When comparing the market's reaction to litigation for foreign and U.S. firms, it is important to consider that news of the litigation may take longer to reach foreign markets. Therefore, Figure 1 graphs the average abnormal returns for the days surrounding the filing of litigation for each of our two samples. It is clear from the graph that the news has the largest impact on the returns of U.S. firms on the actual day of the filing date (day 0). This means that news dissemination in the U.S. is fast; the U.S. market comes to know the bad news about litigation for a U.S. firm the day of the filing. Notice also that, since abnormal return is of small magnitude before the filing date, it implies that news leakage before the filing date is miniscule. ${ }^{12}$ The news has the largest impact on foreign firm returns one and three days (day 1 and day 3) after the case is filed in a U.S. court. This means that news dissemination in the foreign country is slow; it takes the foreign market up to three days after the filing date to know the bad news about litigation for the foreign firm. Because the news does not appear to affect our two samples on the same day, we pick two event windows that will incorporate the majority of the reactions for both samples when calculating abnormal returns. The first window begins the day before the actual filing and continues one day past the filing date (day -1 to day +1 ), while the second window begins one day before filing and continues three days beyond the filing date (day -1 to day +3 ). All our tests are run computing abnormal returns in both windows, and they are basically the same. So we report mostly the results for the day -1 to day +3 window.

${ }^{11}$ We ran all our event studies using two other methodologies, the market-adjusted returns model and comparison-period returns model. Our results do not change. All these three methodologies are described in detail in Panel $\mathrm{C}$ of the Appendix.

${ }^{12}$ We searched for news reports in Factiva for our sample of foreign defendant firms and U.S. defendant firms. We could not find any news reports before the filing date. 
The objective of Table 2 is to compare and contrast the differential market reaction to U.S. firms being sued vs foreign firms being sued. In Table 2, we report OLS estimates of the following model:

$$
\begin{aligned}
& \text { AR }_{i}=\beta_{0}+\beta_{1} * \text { US }_{i}+\beta_{2} * \text { ASSETS }_{i}+\beta_{3} * \text { PROFIT }_{i}+\beta_{4} * \text { LEVERAGE }_{i} \\
& +\sum \beta_{j} * \text { NOS }_{j, i}+\sum \beta_{y} * \text { YEAR }_{y, i}+\sum \beta_{k} * \operatorname{INDUSTRY}_{k, i}
\end{aligned}
$$

where

$A R_{\mathrm{i}}$ is the abnormal return for the defendant firm $\mathrm{i}$;

$U S_{\mathrm{i}}$ is a dummy variable equal to 1 if the defendant firm $\mathrm{i}$ is a U.S. corporation;

ASSETS $_{i}$ is Total Assets for the defendant firm i;

PROFIT $_{i}$ is the ratio of Operating Income to Total Assets for the defendant firm i;

LEVERAGE $E_{i}$ is the ratio of Long-Term Debt to Total Assets for the defendant firm i;

$\operatorname{NOS}_{j, i}$ is a series of dummy variables that equal 1 if the nature of the lawsuit is of type $\mathrm{j}$ for the defendant firm i and 0 otherwise;

$Y E A R_{y, i}$ is a series of dummy variables that equal 1 if the lawsuit is filed in year $y$ for the defendant firm i and 0 otherwise; and

$\operatorname{INDUSTR} Y_{k, i}$ is a series of dummy variables that equal 1 if the defendant firm $\mathrm{i}$ is in industry $\mathrm{k}$ and 0 otherwise;

We use the control variables in four combinations. Model 1 controls for the nature of the lawsuit. Model 2 further controls for year-effects. Model 3 further controls for industry effects. Model 4 further controls for Assets, Profitability, and Leverage of the firm. So Model 4 has all the controls.

Panel A in Table 2 gives the results when the dependent variable is the day -1 to day +1 window, and Panel B in Table 2 gives the results when the dependent variable is the day -1 to day 
+3 window. We notice from both these panels that, whatever the model or whatever the window, the abnormal return at the announcement of litigation is more negative for foreign defendant firms than it is for U.S. defendant firms. The difference is statistically significant for the first two models in day -1 to day 1 window, and is statistically significant for all the models in the day -1 to day 3 window. To get a sense of economic significance, we multiply the market capitalization (share price times number of shares outstanding) of each firm by its abnormal negative return in the three day window (day -1 to day +3 ), and note that the median dollar loss of foreign firms is two and a half times the median dollar loss of U.S. firms ( $\$ 930,000$ versus \$366,000).

One possible explanation for the results in Panel A and B of Table 2 is a sample selection bias. Suppose that the cost of bringing a lawsuit against a foreign firm is higher than the cost of bringing a lawsuit against a U.S. firm, or the probability of recovering damages from a foreign firm is lower than the probability of recovering damages from a U.S. firm If this is the case, then we should expect that a plaintiff will file a lawsuit against a foreign firm only if his probability of winning is high or the expected damages collected are high. If the plaintiff's probability of winning is high or if the expected damages are high, then the abnormal share price reaction of a defendant will be more negative because of this sample selection bias. To address this issue, we apply Heckman's (1979) model in Panel C of Table 2.

In essence, Heckman’s (1979) model fits two equations. The first equation uses all firms, sued or not, to estimate the probability of a lawsuit occurring. We collect information for all foreign firms in Worldscope, whether sued or not, and all U.S. firms in Compustat, again, whether sued or not. We have 46,376 non-sued foreign firms and 43,483 non-sued U.S. firms in the 1995 to 2000 period. We fit the probability of a lawsuit as 


$$
\begin{aligned}
& P_{L i}=N[X \Lambda]= \\
& N\left[\lambda_{0}+\lambda_{1} * U S_{i}+\lambda_{2} * \operatorname{ASSETS}_{i}+\lambda_{3} * \operatorname{PROFIT}_{i}+\lambda_{4} * \operatorname{LEVERAGE}_{i}\right. \\
& \left.+\sum \lambda_{y} * Y E A R_{y, i}+\sum \lambda_{k} * \operatorname{INDUSTR}_{k, i}\right]
\end{aligned}
$$

where

$P_{\mathrm{Li}}$ is the probability of litigation for firm $\mathrm{i}$;

$N(x)$ is a standard normal c.d.f. evaluated at $\mathrm{x}$;

$\mathrm{X}$ is a matrix of independent variables mentioned in equation (2a) and described in equation

$$
\text { (1); and }
$$

$\Lambda$ is a vector of coefficients to be estimated.

Equation (2a) uses only information about the firm and the year, since case information, such as the geographic area of the court, is not available until the lawsuit is filed.

The second equation uses only firms facing a lawsuit. We fit the abnormal returns as

$$
\begin{aligned}
& A_{i}=\beta_{0}+\beta_{1} * \text { US }_{i}+\beta_{2} * \text { ASSETS }_{i}+\beta_{3} * \text { PROFIT }_{i}+\beta_{4} * \text { LEVERAGE }_{i} \\
& +\sum \beta_{j} * \text { NOS }_{j, i}+\sum \beta_{y} * \text { YEAR }_{y, i}+\rho \frac{n\left(X_{i} \Lambda\right)}{N\left(X_{i} \Lambda\right)}
\end{aligned}
$$

where

$n(x)$ and $N(x)$ are, respectively, the standard normal PDF and CDF evaluated at $\mathrm{x}$;

$\Lambda$ is a vector of coefficients that was estimated in equation (2a); and the other independent variables have been described before.

The coefficient on the inverse Mill's ratio, $\rho$, provides a test of whether there is a sample selection problem. Since firms that are sued have information about their case, we do use some case- specific controls in equation (2b). These are given in equation (2b). 
The results from Panel C in Table 2 provide little support for a sample selection problem. First, counter to the argument that the hurdle is higher for suing foreign firms than U.S. firms, the probability of a foreign firm being sued is actually higher than the probability of a U.S. firm being sued. In addition, the inverse Mill's ratio is statistically insignificant, which suggests that the results presented in Panels A and B are not driven by the fact that lawsuits are not random. Nevertheless, even after controlling for this sample selection bias, the abnormal loss at the announcement of litigation is greater for foreign defendant firms than it is for U.S. defendant firms. The difference continues to remain statistically significant and of similar magnitude. ${ }^{13}$

\section{INSERT TABLE 2 HERE}

Table 3 is a more detailed examination of Table 2. We group lawsuits by geographic region: Midwest, Northeast, South, and West. We replace the intercept term with a series of dummy variables that equal 1 if the court is tried in a Midwestern court, a Northeastern court, a Southern court, or a Western court. We want to investigate whether the geographic region matters in the abnormal return. Further, we interact the geographic region dummy variables with the U.S. dummy variable. We want to learn whether the difference between abnormal returns of foreign corporate defendants and U.S. corporate defendants exists in all district courts.

Panel A of Table 3 reports the results of an OLS regression of abnormal returns against the independent variables described above. This panel shows that the difference between share price

${ }^{13}$ We also fit a model which has industry dummies in both equations (2a) and (2b). In it, we still find evidence that U.S. firms have a significantly higher abnormal return than foreign firms. However, because all independent variables are included in both equations, there is severe multicollinearity, and, therefore, unstable parameter estimates. Since the industry effects in Panel B of Table 2 did not substantially change the estimated coefficients in equation (1), we include the industry dummies in equation (2a) only. 
reactions of U.S. and foreign corporate defendants differs substantially by jurisdiction. In Midwestern courts, U.S. firms have a much more negative share price reaction to litigation than do foreign firms. In both Southern and Northeastern courts, there is a much more negative share price reaction for foreign firms than U.S. firms. Western courts show similar reactions for both U.S. and foreign corporate defendants. As we saw in Table 1, as there are more cases in the Northeastern and Southern courts, their effect dominates the effects of Western and Midwestern courts. Panel A of Table 3 is not corrected for the sample selection bias we discussed before.

Panel B of Table 3 corrects for the sample selection bias. The coefficient on the Mill's ratio is again statistically insignificant. As before, this does not support a sample selection bias. Again, the results remain of similar magnitude as those presented in Panel A.

INSERT TABLE 3 HERE

To summarize, from the results in Table 2 and Table 3, we establish a robust stylized fact: though lawsuits against firms are bad news (a result documented before in the literature), they are worse news for foreign firms than for U.S. firms (new result). We now explore the rational foundations of the above result.

\section{Why is corporate litigation less bad news for U.S. firms?}

A judge may dismiss a case before it goes to trial. An obvious hypothesis why litigation is less bad news for U.S. corporate defendants than it is for foreign corporate defendants is that the cases against U.S. corporate defendants are dismissed more often by judges. If the case is not dismissed, then the parties may settle. If U.S. firms can avoid the costs of trial through settlement more often than foreign firms, this may also explain why litigation is less bad news for U.S. firms than for foreign firms. If the case is not settled, then the defendant may win or lose the case. The final 
explanation for why U.S. firms suffer a less negative abnormal return than foreign firms is that U.S. firms win lawsuits more often. Figure 2 shows an illustration of this sequential decision process.

Perloff, Rubinfeld, and Ruud (1996) develop an empirical methodology to address the above sequential decision process. We extend their model. Because of another sample selection bias that we identified in Tables 1, 2 and 3 - the sample of U.S. corporate defendants are different from the sample of foreign corporate defendants - we include this additional sample selection correction in the Perloff, Rubinfeld and Rudd (1996) model.

We fit the probability of a lawsuit as

$$
\begin{aligned}
& P_{L i}=L[X \Theta]= \\
& L\left[\theta_{0}+\theta_{1} * U S_{i}+\theta_{2} * \operatorname{ASSETS~}_{i}+\theta_{3} * \text { PROFIT }_{i}+\theta_{4} * \text { LEVERAGE }_{i}\right. \\
& \left.+\sum \theta_{y} * Y E A R_{y, i}+\sum \theta_{k} * I_{\text {INDUSTRY }}\right]
\end{aligned}
$$

where

$P_{\mathrm{Li}}$ is the probability of litigation for firm i;

$L(x)$ is a logistic CDF evaluated at $\mathrm{x}$;

$\mathrm{X}$ is the matrix of independent variables from equation (2a); and

$\Theta$ is a vector of coefficients to be estimated.

Equation (3) uses only information about the firm and the year, since case information, such as the geographic area of the court, is not available until the lawsuit is filed.

The model begins at the end, fitting the probability that the defendant wins or loses the case, conditional on the fact that the case has not been dismissed or settled. We consider the probability of a defendant win to depend on firm characteristics. Our model for a defendant win is 


$$
\begin{aligned}
& P_{W i}=L[W \Omega]= \\
& L\left[\sum \omega_{0, r} * R E G I O N_{r, i}+\sum \omega_{1, r} * U S_{i} * R_{E G I O N}\right. \\
& +\omega_{2} * \text { ASSETS }_{i}+\omega_{3} * \text { PROFIT }_{i}+\omega_{4} * \text { LEVERAGE }_{i} \\
& \left.+\sum \omega_{j} * N O S_{j, i}+\sum \omega_{y} * Y E A R_{y, i}+\rho_{W} \frac{l\left(X_{i} \Theta\right)}{L\left(X_{i} \Theta\right)}\right]
\end{aligned}
$$

where

$P_{W i}$ is the probability of a defendant i win;

$I[x]$ and $L[x]$ are, respectively, the PDF and CDF for the logistic distribution evaluated at $\mathrm{x}$;

$\Omega$ is a vector of coefficients that will be estimated;

$\Theta$ is a vector of coefficients that was estimated in equation (3);

REGION $_{r, i}$ is a series of dummy variables that equal 1 if firm $\mathrm{i}$ is sued in region $\mathrm{r}$ (the regions are Northeast, South, West and Midwest), and 0 otherwise; and the other variables have been described before.

The model now goes back one step to the settlement decision. Parties to litigation are more likely to settle when there is agreement as to the outcome. Therefore, when the probability of a defendant win is close to either 0 or 1, the parties will more likely settle (Priest and Klein (1984)). To address this self selection issue, the probability of settling includes the variance of outcomes if the case proceeds to trial. The variance is the predicted probability of a defendant win times the predicted probability of a defendant loss. Perloff, Rubinfeld, and Ruud (1996) provide evidence supporting this idea. We include other controls in the settlement equation as well. Our model for the probability of settlement is, therefore, 


$$
\begin{aligned}
& P_{S i}=L[S \Gamma]= \\
& L\left[\sum \gamma_{0, r} * R_{E G I O N}+\sum \gamma_{r, i} * \operatorname{REGION}_{r, i} * U S_{i}\right. \\
& \left.+\gamma_{2} * P_{W i} *\left(1-P_{W i}\right)+\gamma_{3} * P_{W i} *\left(1-P_{W i}\right) * U S_{i}+\sum \gamma_{y, 1} * \text { Year }_{y, i}\right]
\end{aligned}
$$

where

$P_{S i}$ is the probability of a settlement of firm i

$P_{W i}$ is the probability of a settlement of firm i estimated as in (4a);

$\Gamma$ is a vector of coefficients that will be estimated; and

the other variables have been described before.

The model now goes back one step to the dismissal decision. The decision is likely to depend on where the case is heard, as different judges may interpret motions to dismiss differently. In addition, we control for year effects in dismissal rates by including a dummy variable. Our model for the probability of dismissal is

$$
\begin{aligned}
& P_{D i}=L[D \Delta]= \\
& L\left[\sum \delta_{0, r} * \operatorname{REGION}_{r, i}+\sum \delta_{1, r} * U_{i} * \operatorname{REGION}_{r, i}\right. \\
& +\delta_{2} * \text { ASSETS }_{i}+\delta_{3} * \operatorname{PROFIT}_{i}+\delta_{4} * \operatorname{LEVERAGE}_{i} \\
& \left.+\sum \delta_{j} * \operatorname{NOS}_{j, i}+\sum \delta_{y} * Y E A R_{y, i}+\rho_{D} \frac{l\left(X_{i} \Theta\right)}{L\left(X_{i} \Theta\right)}\right]
\end{aligned}
$$

where

$P_{D i}$ is the probability of a dismissal of a case against firm I;

$\Delta$ is a vector of coefficients that will be estimated;

$\Theta$ is a vector of coefficients that was estimated in equation (3); and the other variables have been described before. 
Equations (4a) and (4b) are estimated simultaneously by maximum likelihood. Since (5) is independent of the other equations, we fit it separately using maximum likelihood. The models are fit assuming that the steps in the litigation process have a joint logistic distribution. Note also that, besides correcting for the self-selection of cases that go to trial - a point first made by Priest and Klein (1984) - using the Perloff, Rubinfeld, and Ruud (1996) method, we also correct for the fact that the sample of foreign corporate defendants is different from the sample of U.S. corporate defendants using the Heckman (1979) correction. The results from this estimation are given in Tables 4 and 5 .

Table 4 documents the main result of our paper. Model 2 has all the controls of Model 1 plus three others: assets, profitability and leverage. So we discuss the results from Model 2 in Table 4. It seems that U.S. defendant firms are as likely to have their cases dismissed against them as foreign defendant firms. If the case is not dismissed, it seems that U.S. defendant firms are as likely to settle as foreign defendant firms. However, if the case is not settled, it seems that U.S. defendant firms are more likely to win in trial than foreign defendant firms. A further test, the log likelihood ratio test, confirms this last and most important finding (a p-value of 0.043 suggests that the U.S. dummy is an important determinant of who wins.)

The difference is also economically significant. A foreign corporate defendant has a $63 \%$ chance of winning a product liability lawsuit in 2000, whereas a U.S. corporate defendant has a 78\% chance of winning a product liability lawsuit in 2000.

\section{INSERT TABLE 4 ABOUT HERE}

Table 5 is a detailed examination of Table 4. It seems that U.S. defendant firms are as likely to have cases dismissed against them as foreign defendant firms in all regions. If the case is not 
dismissed, it seems that U.S. defendant firms are more likely to settle than foreign defendant firms in the Northeast and in the West. Finally, if the case is not settled, it seems that U.S. defendant firms are more likely to win in trial than foreign defendant firms in the Northeast and in the West. So it seems that the bias against foreign firms is concentrated in the Northeast and in the West. A further test, the log likelihood ratio test, confirms this last and most important finding (a p-value of 0.005 suggests that the U.S. dummy is an important determinant of who wins, whereas a p-value of 0.014 suggests that the discrimination against foreign firms is region-specific.)

\section{INSERT TABLE 5 ABOUT HERE}

Till now we have focused only on the nationality of the defendant, but not on the nationality of the plaintiff. The reason is because it is very difficult to obtain the nationality of the plaintiff. The ICPSR (Interuniversity Consortium of Political and Social Research) database, however, allows us to obtain the U.S. citizenship or the lack thereof of the plaintiff if the plaintiff is an individual and if the case is in federal court because of diversity of residence of the plaintiff and the defendant.

Table 6 summarizes the results from this smaller sample, where the U.S. citizenship or the lack thereof of the defendants and the plaintiffs have been identified. We find that abnormal stock returns are higher and probability of a defendant win is higher if a U.S. corporate defendant fights against a foreign plaintiff than if a foreign corporate defendant fights against a U.S. plaintiff, though the differences, given the small sample sizes, are not statistically different.

\section{INSERT TABLE 6 HERE}

\section{More Tests to Control for Sample Selection Biases}

We have controlled for one type of sample selection bias - cases that go to trial are cases that could not be settled - using the Perloff, Rubinfeld, and Ruud (1996) methodology. We have 
controlled for another type of sample selection bias - lawsuits are not random, but are instances where the plaintiffs believe that their benefits from suing outweigh their cost - by three ways. First, we controlled for defendant characteristics like size, profitability, leverage and industry, and lawsuit characteristics like the type of lawsuit, year of lawsuit and the jurisdiction of lawsuit. Second, we directly controlled for the probability of a lawsuit using Heckman's (1979) method. Third, we provided some indirect evidence against the sample selection bias. It is argued - see page 610 in Posner (1998) -that if the stakes are high, everything else equal, litigation is more likely. The intuition is that as now the stakes dominate the dead-weight costs of litigation in a probabilistic sense, litigation is more likely than settlement. If this is the case, our selection bias hypothesis, as it is based on the assumption that foreign firms are sued only when the stakes are higher, would predict more litigation and less settlement in the case of foreign firms. We did not find that on an average.

The fourth group of tests to check for this selection bias is inspired from a consensus that is emerging in international finance: foreign firms listed in the U.S. as ADRs are worth more than similar foreign firms listed in their home countries because they “rent” U.S. laws. There is some debate about the direction of causality. Most papers consider listing to be the cause of value, whereas in an important paper, Doidge, Karolyi and Stulz (2003) make the argument that a subset of foreign firms whose growth opportunities are high separate themselves from the pack by voluntarily listing in the U.S. and thus credibly making a commitment to extract less private benefits. Siegel (2005) offers an alternate "renting reputation" hypothesis to the "renting law" hypothesis.

If foreign firms that list in the U.S. do indeed rent U.S. laws, this would imply that it is easier to collect from foreign firms with ADRs than from foreign firms without ADRs. So, the hurdle for lawsuits against foreign firms with ADRs should be lower than the hurdle for lawsuits against 
foreign firms without ADRs. According to our selection bias hypothesis, this would mean that lawsuits against foreign firms without ADRs occur only when the stakes are higher and/or the probability of a plaintiff win is higher. If this is the case, we should expect fewer dismissals of cases against foreign firms without ADRs, and, if a case goes to trial, we should expect foreign firms without ADRs to lose more often than foreign firms with ADRs. Moreover, if the markets are efficient, we should expect the share price reaction to be more negative for foreign firms without ADRs than it is for foreign firms with ADRs.

Table 7 gives descriptive statistics on the sample of foreign corporate defendants with ADRs and foreign corporate defendants without ADRs in U.S. federal lawsuits. The objective of Table 7 is to analyze whether the samples are starkly different.

As can be seen in Table 7, the two types of foreign corporate defendants are different in characteristics. Foreign corporate defendants that have ADRs listed in the U.S. are bigger than foreign corporate defendants that do not have ADRs listed in the U.S., both in terms of sales as well as in size of assets. This is to be expected, from both the supply side as well as the demand side. From the supply side, only visible firms (visibility as measured in terms of size or sales) find it worthwhile to list themselves in U.S. stock exchanges. From the demand side, U.S. exchanges only allow firms above a certain size to list ADRs in the U.S. Interestingly, we find that foreign corporate defendants that do not have ADRs listed in the U.S. seem to have deeper pockets than foreign corporate defendants that have ADRs listed in the U.S., whether deep pockets are measured in profitability, free cash flow or valuation (market-to-book ratio). Finally, the leverage of foreign defendant firms with ADRs is higher than the leverage of foreign defendant firms without ADRs. There is also some difference in the type of litigation. Product liability is the most popular alleged 
violation for foreign firms without ADRs, whereas patent infringement is the most popular alleged violation for foreign firms with ADRs.

\section{INSERT TABLE 7 HERE}

The objective of Table 8 is to formally check whether foreign defendant firms with ADRs suffer less abnormal price drop than foreign defendant firms without ADRs, as the selection bias hypothesis will predict. Table 8 provides results from a multi-variate OLS regression, where the dependent variable is the abnormal return at the announcement of litigation, and the independent variables are the control variables. The control variables are size, profitability, leverage, litigation type, region, industry and year. So Table 8 is similar to Panel A of Table 3. The only difference is that our sample is now just foreign defendant firms and, therefore, no Heckman (1979) correction is needed.

We find in Table 8 that the share price reaction at the announcement of litigation is statistically indistinguishable between foreign defendant firms with ADRs and foreign defendant firms without ADRs when all the control variables are put in. A detailed examination of the regions shows us that the reaction is statistically the same in all regions. This is evidence against the selection bias hypothesis.

\section{INSERT TABLE 8 HERE}

An important criticism of using event studies is that abnormal returns reflect only surprises. It could be that abnormal returns are more negative for foreign corporate defendants than for U.S. corporate defendants not because the former are more disadvantaged than the latter in U.S. courts, but because the litigation announcement was a bigger surprise for the foreign firm than for the U.S.

firm. If this logic held, as foreign firms with ADRs are more visible and more followed by analysts 
than foreign firms without ADRs - see Lang, Lins and Miller (2003) - then the litigation announcement should be less negative for foreign firms with ADRs than for foreign firms without ADRs. We do not see this in Table 8. So the above criticism is not damning in our study.

The objective of Table 9 is to formally check whether foreign defendant firms with ADRs have different litigation outcomes than foreign defendant firms without ADRs, as the selection bias hypothesis will predict. Table 9, employing the Perloff, Rubinfeld, and Ruud (1996) model outlined in equations 4(a), 4(b) and 5 checks this. The model follows the same logic as that in Table 4 . We find that dismissal rates, settlement rates, and win rates for foreign corporate defendants with ADRs are statistically indistinguishable from the respective dismissal rates, settlement rates, and win rates of foreign corporate defendants without ADRs in all regions in the U.S.

\section{INSERT TABLE 9 HERE}

To summarize, the market reactions at the announcement of litigation and the dismissal rates, settlement rates and win rates are statistically indistinguishable between foreign firms with ADRs and foreign firms without ADRs. All of this is evidence against the sample selection bias hypothesis, which had predicted more negative market reactions, lower dismissal rates, and lower win rates for foreign defendant firms without ADRs than for foreign defendant firms with ADRs.

Finally, for our fifth set of tests, we try to obtain information on damages awarded. This information is available only for 23 foreign firms and 62 U.S. firms. We find that the median damage award is higher for U.S. firms than for foreign firms (USD125,000 vs USD 85,000) but the mean damage award is lower for U.S. firms than for foreign firms (USD 983,000 vs USD 2,247,000). However, the difference in medians or means is not statistically significant.

We, hence, are not able to rule out the hypothesis that U.S. firms have a home court advantage 
in U.S. federal courts.

\section{Why are U.S. firms advantaged in U.S. courts?}

We now look at reasons why U.S. firms may be advantaged in U.S. courts. U.S. firms may have more skill in dealing with the U.S. justice system than do foreign firms. Though we do not have data to provide formal evidence for or against this hypothesis, we do not believe this could be an important explanation. The reason is that the foreign firms can hire the same good lawyers as U.S. firms can. ${ }^{14}$

A second reason why U.S. firms may be advantaged in U.S. courts is that judges or juries are likely to be more sympathetic to U.S. defendant firms than they are to foreign defendant firms. Clermont and Eisenberg (1996) found from a sample of civil cases that foreigners win a higher proportion of cases than do domestic parties, whereas Moore (2003), in a careful study of only patent infringement cases, finds the reverse. Our paper supports the conclusion of Moore (2003): foreign firms are disadvantaged in U.S. courts. Moore (2003) also finds that juries, not judges, seem to be biased. Table 10 checks whether indeed U.S. corporate defendants win more often in U.S. federal courts than do foreign corporate defendants if it is a jury trial. We use a logit model in which the dependent variable is 1 if the defendant wins, and 0 otherwise. We fit this model on the set of firms that actually go to trial. Thus, this is the last stage in the model used in Table 4. The control variables are size, profitability, year, litigation type, and industry fixed effects, plus four indicator variables for each of the four combinations of jury or judge and U.S. or foreign.

14 A search under the keywords “international corporate litigation” in Google turned up advertisements from numerous blue-blood law firms, like Baker and McKenzie, that defend foreign firms in U.S. courts. 
Controlling for the region in which the case is tried, size, profitability, year, litigation type, and industry fixed effects, the probability of win is higher for a U.S. defendant firm in a judge trial than in a jury trial. For foreign defendant firms, it does not seem to matter. In fact, U.S. firms in a jury decision and foreign firms in either a judge or jury decision have statistically indistinguishable win rates. This seemingly contradicts the finding of Moore (2003), who found prejudice in the jury.

\section{INSERT TABLE 10 HERE}

The psychology literature - see Cashden (2001) - suggests that there is less bias against foreigners who are similar. So we do further analysis to see whether the bias is more against firms from countries that do not have English as an official language as opposed to firms from countries that have English as an official language, whether the bias is more against firms from countries that do not have whites as their majority race as opposed to firms from countries that have whites as their majority race, and whether the bias is more against firms from countries that do not have Christianity as their major religion as opposed to firms from countries that have Christianity as their major religion. All these data come from the CIA World Factbook $2001 .^{15}$

We find no difference in the biases using the above country-specific variables. ${ }^{16}$ This could simply be because we do not have enough data to detect significant cross-country variation.

We also test whether there is less bias against foreign firms who have more sales in the U.S. or have more of their assets in the U.S., but we find no such significant correlation.

\footnotetext{
${ }^{15}$ http://www.cia.gov/cia/publications/factbook

${ }^{16}$ These tables are available from the authors upon request.
} 


\section{Conclusion}

This paper uses data (stock prices), methodologies (event study econometrics) and stylized facts (some foreign firms "rent” U.S. laws by listing themselves in the U.S.) from financial economics to address the fairness of international corporate litigation in U.S. federal courts.

Using a comprehensive sample of 2,361 public U.S. corporate defendants and 715 foreign corporate defendants in U.S. federal courts in the period 1995-2000, the paper finds that the market reaction at the announcement of a U.S. federal lawsuit is less negative for U.S. corporate defendants. This market reaction turns out to be rational. We find that the dismissal rates for U.S. defendant firms are not reliably different from dismissal rates for foreign defendant firms, but, if the case went to trial, U.S. firms are less likely to lose than a foreign firm.

It may be premature to conclude from the above that U.S. firms have a comparative advantage over foreign firms in U.S. federal courts. The reason is a simple sample selection bias. We can argue that as it is difficult to collect from foreign firms, the only foreign firms that are sued are the ones where the claimed damages and/or the ex-ante probability of a defendant loss is higher. In other words, the lawsuits against foreign firms are more serious. If this is the case, we should expect fewer dismissals of cases against foreign firms and, if a case goes to trial, we should expect foreign firms to lose more often than U.S. firms. Moreover, if the markets are efficient, we should expect the share price reaction to be more negative for foreign firms than it is for U.S. firms.

We devise five tests to detect this bias. First, we try to mitigate the sample selection bias by controlling for size, profitability, year, industry and type of litigation. Our results remain. Second, we control for the probability of being sued. Our results remain. Third, if the cases against foreign firms are more serious, foreign firms should settle more often. We do not find that. Fourth, if the 
cases against foreign firms are more serious, the cases against foreign firms that do not list in the U.S. should be even more serious as it is more difficult to collect from them. We do not find that. Fifth, we find that the level of damages awarded is about the same for U.S. defendant firms than foreign defendant firms. In short, though the two samples are different in characteristics - the U.S. corporate defendants are smaller, but have deeper pockets than foreign corporate defendants - the paper finds little evidence of a sample selection bias that explains the results.

We thus cannot rule out that U.S. firms have a home court advantage in U.S. federal courts. This could be because foreign firms have lower quality legal counsel and/or juries and judges are prejudiced against foreign firms. Though we do not provide any formal evidence, we doubt it is because of the former reason. Moore (2003), using a different data set and a different methodology, also concludes that there is a prejudice against foreign firms in U.S. courts. She finds the prejudice in the jury, whereas we find the prejudice in the judges. 


\section{Appendix}

Definition of variables and data sources

Panel A: Legal Variables

\begin{tabular}{|c|c|c|c|}
\hline Variable & Description & $\begin{array}{l}\text { Source } \\
\text { for US } \\
\text { firms }\end{array}$ & $\begin{array}{l}\text { Source } \\
\text { for } \\
\text { foreign } \\
\text { firms }\end{array}$ \\
\hline $\begin{array}{l}\text { Nature of Lawsuit } \\
\text { Antitrust } \\
\text { Contract } \\
\text { Patent } \\
\text { Employee } \\
\text { Product Liability }\end{array}$ & $\begin{array}{l}=1 \text { if lawsuit is Antitrust, } 0 \text { otherwise } \\
=1 \text { if lawsuit is breach of Contract, } 0 \text { otherwise } \\
=1 \text { if lawsuit is Patent infringement, } 0 \text { otherwise } \\
=1 \text { if lawsuit is Employment-related, } 0 \text { otherwise } \\
=1 \text { if lawsuit is about Product liability, } 0 \text { otherwise }\end{array}$ & PACER & PACER \\
\hline $\begin{array}{l}\text { Dates } \\
\text { Filing Date } \\
\text { (= Event Date) } \\
\text { Closing Date }\end{array}$ & $\begin{array}{l}\text { Date the lawsuit was filed } \\
\text { Date the lawsuit was closed }\end{array}$ & PACER & PACER \\
\hline Dismissal Rate & $\begin{array}{l}\text { Number of cases dismissed by judge/Number of } \\
\text { cases for which we know the outcome }\end{array}$ & PACER & PACER \\
\hline Settlement Rate & $\begin{array}{l}\text { Number of cases settled/Number of cases for which } \\
\text { we know the outcome }\end{array}$ & PACER & PACER \\
\hline $\begin{array}{l}\text { Win Rate } \\
\text { (= } 1 \text { - Loss Rate) }\end{array}$ & $\begin{array}{l}\text { Number of cases the defendant won/Number of } \\
\text { cases for which we know the outcome, and which } \\
\text { were not settled nor dismissed }\end{array}$ & PACER & PACER \\
\hline $\begin{array}{l}\text { Decision Maker } \\
\text { Judge } \\
\text { Jury }\end{array}$ & $\begin{array}{l}=1 \text { if judge decides, } 0 \text { otherwise } \\
=1 \text { if jury decides, } 0 \text { otherwise }\end{array}$ & PACER & PACER \\
\hline
\end{tabular}


Panel B: Firm-Specific Variables

\begin{tabular}{|l|l|l|l|}
\hline \multicolumn{1}{|c|}{ Variable } & \multicolumn{1}{|c|}{ Description } & \multicolumn{1}{|c|}{$\begin{array}{l}\text { Source for } \\
\text { US firms }\end{array}$} & $\begin{array}{l}\text { Source for } \\
\text { foreign } \\
\text { firms }\end{array}$ \\
\hline Industry & Fama-French 10 industry classification & $\begin{array}{l}\text { Ken } \\
\text { French's } \\
\text { website }\end{array}$ & $\begin{array}{l}\text { Ken } \\
\text { French's } \\
\text { website }\end{array}$ \\
\hline Sales & Total revenues in year of filing & Compustat & Worldscope \\
\hline Assets & Book value of total assets at the end of 2001 & Compustat & Worldscope \\
\hline Profit & Operating income / Total assets & Compustat & Worldscope \\
\hline Free Cash Flow & $\begin{array}{l}\text { (Net income + Depreciation - Dividends) / } \\
\text { Total assets }\end{array}$ & Compustat & Worldscope \\
\hline Leverage & Long-term debt / Total assets & Compustat & Worldscope \\
\hline Market Value & $\begin{array}{l}\text { Total assets - Book equity + Market value of } \\
\text { equity }\end{array}$ & Compustat & Worldscope \\
\hline $\begin{array}{l}\text { Market to Book } \\
\text { Ratio }\end{array}$ & Market value / Book Value & Compustat & Worldscope \\
\hline Abnormal return & $\begin{array}{l}\text { Daily return adjusted by expected return } \\
\text { using market model. }\end{array}$ & CRSP & Datastream \\
\hline ADR & $\begin{array}{l}=1 \text { if foreign firm has issued ADR in US } \\
\text { markets, 0 otherwise }\end{array}$ & $\begin{array}{l}\text { Bank of } \\
\text { New York }\end{array}$ \\
\hline
\end{tabular}

\section{Panel C: Abnormal Returns in Event Studies}

To gauge whether shareholders view litigation to be good news, neutral news, or bad news for the defendant firm, financial economics tells us to document how shareholders trade at the announcement of the news. A classic methodology to analyze this is an event study. Assuming that the announcement of litigation will be reflected in traded asset prices, a careful analysis of trading behavior and the price reaction during the announcement of litigation will tell us what shareholders

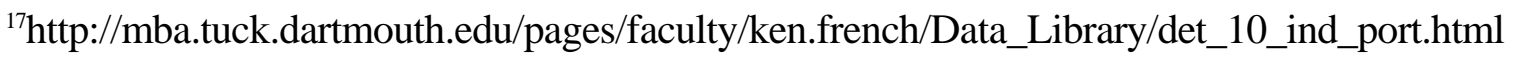


think. ${ }^{18}$ Bhagat and Romano (2002) provide an excellent survey on the use of event studies in the legal domain.

The following equation defines an abnormal return of a stock:

$\mathrm{AR}_{\mathrm{i}, \mathrm{t}}=\mathrm{R}_{\mathrm{i}, \mathrm{t}}-\mathrm{E}\left(\mathrm{R}_{\mathrm{i}, \mathrm{t}}\right)$

where

$R_{i, t}$ is the actual percent change in share price of stock $i$ on day t, i.e., $R_{i, t}=\left(P_{i, t}-P_{i, t-1}\right) /\left(P_{i, t-1}\right)$,

$\mathrm{P}_{\mathrm{i}, \mathrm{t}}$ is the share price (dividend and split adjusted) of stock $\mathrm{i}$ at end of trading day $\mathrm{t}$,

$\mathrm{E}\left(\mathrm{R}_{\mathrm{i}, \mathrm{t}}\right)$ is the "normal" return of stock $\mathrm{i}$ that was expected on day $\mathrm{t}$, and

$\mathrm{AR}_{\mathrm{i}, \mathrm{t}}$ is the abnormal percent change in share price of stock $\mathrm{i}$ on day $\mathrm{t}$.

As the "normal" return is defined as the return that "would have happened had the event not occurred," the abnormal return is a valid measure of the effect of an event on a stock on date t. The total effect of an event on a stock in a period is just the cumulative abnormal return, defined as

$\mathrm{CAR}_{\mathrm{i}}(-\mathrm{b}, \mathrm{e})=\mathrm{AR}_{\mathrm{i}, \mathrm{b}}+\mathrm{AR}_{\mathrm{i}, \mathrm{b}+1}+\ldots+\mathrm{AR}_{\mathrm{i}, 0}+\mathrm{AR}_{\mathrm{i}, 1}+\ldots+\mathrm{AR}_{\mathrm{i}, \mathrm{e}}$

where

$\mathrm{CAR}_{\mathrm{i}}(-\mathrm{b}, \mathrm{e})$ is the cumulative abnormal return from -b days before the event to e days after the event. The event day in event time is denoted as day 0.

The above is for one stock. Event studies generally ask whether one particular event - in our case, the announcement of litigation - systematically affects the share prices of all the $\mathrm{N}$ stocks in which the event happens. To do this, we compute $\operatorname{CAR}_{i}(-b, e)$ for $i=1,2, \ldots N$, and then average them.

${ }^{18}$ Ball and Brown (1968), and Fama et al. (1969) pioneered the classic event study methodology and, except, for minor modifications (see Salinger (1992)), their methodology continues to be used. Campbell et al. (1997) provide an excellent exposition of the event-study methodology in Chapter 4 of their book. 
We then ask whether the average is statistically significant. The usual test is a t-test.

Event studies have two advantages. First, as event windows are small (typically less than four days), this method is a relatively clean measure of the effect of an event that has not been corrupted by the effect of other events. Second, as this method averages the cumulative abnormal returns across many stocks, the firm-specific transient component of abnormal returns is washed out. So if the average cumulative abnormal return is found to be statistically significant, we can conclude that the event systematically affected share prices of all concerned stocks around the day it occurred. In other words, if the cumulative abnormal return was significantly positive (negative) for the sample as a whole, the concerned stocks seemed to have a permanent jump in prices (permanent fall in prices) when the event occurred.

Event studies have one big disadvantage. How do we estimate $E\left(\mathrm{R}_{\mathrm{i}, \mathrm{t}}\right)$, the "normal” return, which is defined as the return that "would have happened had the event not occurred"? The literature has used three methods.

The first method, called the "constant-means-return-model” or "comparison-period-returnsmodel”assumes that the "normal” return of a stock is its long-term mean return. So

$\mathrm{E}\left(\mathrm{R}_{\mathrm{i}, \mathrm{t}}\right)=\mu_{\mathrm{i}}$

where

$\mu_{\mathrm{i}}$ is the long-term mean return of stock $\mathrm{i}$, typically estimated from 270 days before the event to 30 days before the event.

The second method, called the "market-adjusted-returns-model" assumes that the "normal" return of a stock is the market return. So

$\mathrm{E}\left(\mathrm{R}_{\mathrm{i}, \mathrm{t}}\right)=\mathrm{R}_{\mathrm{m}, \mathrm{t}}$ 
where

$\mathrm{R}_{\mathrm{m}, \mathrm{t}}$ is the market return on date $\mathrm{t}$.

The third, and the most sophisticated method, called the "market model" assumes that the "normal” return of a stock is the return that is caused by market movements. So

$E\left(R_{i, t}\right)=\beta_{i} R_{m, t}$

where

$\mathrm{R}_{\mathrm{m}, \mathrm{t}}$ is the market return on date $\mathrm{t}$, and

$\beta_{\mathrm{i}}$ is the sensitivity of stock i to the market return. This is typically estimated by running a OLS regression of $R_{i, t}$ (stock i's return on date t) against $R_{m, t}$ in the period 270 days before the event to 30 days before the event. The coefficient of $R_{m, t}$ is an estimate of $\beta_{i}$. 


\section{REFERENCES}

Ball, R., and P. Brown, 1986, “An Empirical Evaluation of Accounting Income Numbers,” Journal of Accounting Research, 6, 159-178.

Bhagat, S., J. Brickley, and J. Coles, 1994, “The Wealth Effects of Interfirm Lawsuits: Evidence from Corporate Lawsuits,” Journal of Financial Economics, 35, 221-247.

Bhagat, S., J. Bizjak, and J. Coles, 1998, “The Shareholder Wealth Implications of Corporate Lawsuits,” Financial Management, 27, 5-27.

Bhagat, S., and R. Romano, 2002, "Event Studies and the Law - Part I: Technique and Corporate Litigation,” American Law and Economics Review, 4, 141-168.

Bizjak, J., and J. Coles, 1995, “The Effect of Private Antitrust Litigation on the Stock Market Valuation of the Firm,” American Economic Review, 85, 436-461.

CIA World Factbook. 2001.

Campbell, J., A. Lo, and A. C. MacKinlay, 1997, The Econometrics of Financial Markets, Princeton University Press, Princeton, NJ.

Cashden, E., 2001, “Ethnocentrism and Xenophobia: A Cross-Cultural Study,” Current Anthropology, 42, 760-765.

Clermont, K., and T. Eisenberg, 1996, “Xenophilia in American Courts,” Harvard Law Review, 109, 1120-1143.

Cutler, D., and L. Summers, 1987, “The Costs of Conflict Resolution and Financial Distress: Evidence from the Texaco-Penzoil Litigation,” Rand Journal of Economics, 19, 157-172.

Doidge, C., G. A. Karolyi, and R. Stulz, 2004, "Why Are Foreign Firms Listed in the U.S. Worth More?” Journal of Financial Economics 71, 205-238.

The Economics of U.S. Tort Liability: A Primer. 2003, Central Budget Office, Washington, D.C. 
Economist. January 8, 2004.

Eisenberg, T., 1990, “Testing the Selection Effect: A New Theoretical Framework with Empirical Tests,” Journal of Legal Studies 19, 337-358.

Engelman, K., and B. Cornell, 1988, "Measuring the Costs of Corporate Litigation: Five Case Studies,” Journal of Legal Studies, 17, 377-399.

Fama, E., L. Fisher, M. Jensen, and R. Roll, 1969, “The Adjustment of Stock Prices to New Information,” International Economic Review, 10, 1-21.

Haslem, B., 2005, “Managerial Opportunism During Corporate Litigation,” Journal of Finance 60, 2013-2041.

Heckman, J., 1979, “Sample Selection Bias as a Specification Error,” Econometrica 47, 153-161.

Hylton, K., 1993, “Asymmetric Information and the Selection of Disputes for Litigation,” Journal of Legal Studies 22, 187-210.

Karpoff, J., and J. Lott, 1993, “The Reputational Penalty Firms Bear from Committing Criminal Fraud,” Journal of Law and Economics, 36, 757-802.

Karpoff, J., and J. Lott, 1999, “On the Determinants and Importance of Punitive Damage Awards,” Journal of Law and Economics, 42, 527-573.

Moore, K., 2003, “Xenophobia in American Courts,” Northwestern University Law Review, 97, 14971550.

Perloff, J., D. Rubinfeld and P. Rudd, 1996, “Antitrust Settlements and Trial Outcomes,” The Review of Economics and Statistics 78, 401-409.

Posner, R., 1998, Economic Analysis of Law, Aspen Law and Business, New York.

Priest, G., and B. Klein, 1984. “The Selection of Disputes for Litigation,” Journal of Legal Studies, 13, 1-55. 
Salinger, M., 1992, “Standard Errors in Event Studies,” Journal of Financial and Quantitative Analysis, 27, 39-53.

Shavell, S., 1996, “Any Frequency of Plaintiff Victory at Trial is Possible,” Journal of Legal Studies 25, 493-501.

Siegel, J., 2005, “Can Foreign Firms Bond Themselves Effectively by Renting U.S. Securities Laws?” Journal of Financial Economics 75, 319-359.

Siegelman, P., and J. Waldfogel, 1999, “Toward a Taxonomy of Disputes: New Evidence Through the Prism of the Priest/Klein Model,” Journal of Legal Studies 28, 101-130.

Waldfogel, J., 1995, "The Selection Hypothesis and the Relationship Between Trial and Plaintiff Victory,” Journal of Political Economy 103, 229-260.

Wall Street Journal. February 14, 1996

Wall Street Journal. November 11, 2003.

White, H., 1980, “A Heteroscedasticity-Consistent Covariance Matrix Estimator and a Direct Test for Heteroscedasticity,” Econometrica, 48, 817-838.

Wittman, D., 1985, “Is the Selection of Cases for Trial Biased?” Journal of Legal Studies 14, 185214. 
Table 1

U.S. Corporate Defendants vs Foreign Corporate Defendants in U.S. Federal Lawsuits: Summary Statistics

\begin{tabular}{|c|c|c|c|c|c|c|c|c|}
\hline & \multicolumn{3}{|c|}{$\begin{array}{c}\text { U.S. Corporate } \\
\text { Defendant }\end{array}$} & \multicolumn{3}{|c|}{$\begin{array}{c}\text { Foreign Corporate } \\
\text { Defendant }\end{array}$} & \multirow{2}{*}{$\begin{array}{c}\text { P-value for } \\
\text { Differences } \\
\text { Mean } \\
\text { (Median) }\end{array}$} \\
\hline & & \multicolumn{2}{|c|}{$\begin{array}{c}\text { Mean } \\
\text { (Median) }\end{array}$} & $\mathrm{N}$ & $\begin{array}{c}\text { Mean } \\
\text { (Median) }\end{array}$ & \multicolumn{2}{|c|}{$\mathrm{N}$} & \\
\hline \multicolumn{2}{|l|}{ Sales (Millions) } & \multicolumn{2}{|c|}{4,772} & 1,986 & $\begin{array}{r}8,197 \\
(1,765)\end{array}$ & \multicolumn{2}{|r|}{615} & $\begin{array}{l}.0001^{* * *} \\
(.0001)^{* * *}\end{array}$ \\
\hline \multicolumn{2}{|l|}{ Assets (Millions) } & $\begin{array}{l}6,80 \\
(94\end{array}$ & & 1,987 & $\begin{array}{r}8,907 \\
(1,929)\end{array}$ & \multicolumn{2}{|r|}{615} & $\begin{array}{c}.141 \\
(.0001)^{* * *}\end{array}$ \\
\hline \multicolumn{2}{|l|}{ Profit (\% of Assets) } & \multicolumn{2}{|c|}{$\begin{array}{l}14.03 \\
(14.94)\end{array}$} & 1,974 & $\begin{array}{l}5.22 \\
(5.03)\end{array}$ & \multicolumn{2}{|r|}{615} & $\begin{array}{l}.0001^{* * *} \\
(.0001)^{* * *}\end{array}$ \\
\hline \multicolumn{2}{|c|}{ Free Cash Flow (\% of Assets) } & \multicolumn{2}{|c|}{$\begin{array}{l}6.91 \\
(8.61)\end{array}$} & 1,987 & $\begin{array}{l}5.08 \\
(5.43)\end{array}$ & \multicolumn{2}{|r|}{501} & $\begin{array}{c}.012 * * \\
(.0001)^{* * *}\end{array}$ \\
\hline \multicolumn{2}{|l|}{ Leverage (\% of Assets) } & \multicolumn{2}{|c|}{$\begin{array}{l}24.09 \\
(22.29)\end{array}$} & 1,980 & $\begin{array}{l}14.38 \\
(12.71)\end{array}$ & \multicolumn{2}{|r|}{615} & $\begin{array}{l}.0001^{* * *} \\
(.0001)^{* * *}\end{array}$ \\
\hline \multirow[t]{2}{*}{ Market to Book Ratio } & & \multicolumn{2}{|c|}{$\begin{array}{l}1.99 \\
(1.57)\end{array}$} & 1,849 & $\begin{array}{r}1.66 \\
(1.34) \\
\end{array}$ & & 599 & $\begin{array}{l}(.0001)^{* * *} \\
(.0001)^{* * *}\end{array}$ \\
\hline & U.S. & Corporat & Defel & ant & Foreig & Corpo & rate Det & efendant \\
\hline Nature of Suit & Dismiss & Settle & Win & Lose & Dismiss & Settle & Win & n Lose \\
\hline Antitrust & 28 & 96 & 28 & 4 & 8 & 15 & 6 & 0 \\
\hline Contract & 10 & 62 & 8 & 6 & 2 & 13 & 3 & 1 \\
\hline Employee & 16 & 189 & 21 & 9 & 3 & 28 & 4 & 3 \\
\hline Patent & 72 & 544 & 80 & 24 & 16 & 174 & 10 & 14 \\
\hline Product Liability & 61 & 529 & 105 & 15 & 20 & 208 & 35 & 5 \\
\hline Industry & & & & & & & & \\
\hline Non-Durables & 15 & 75 & 17 & 3 & 1 & 22 & 4 & 1 \\
\hline Durables & 3 & 37 & 3 & 4 & 1 & 20 & 1 & 0 \\
\hline Manufacturing & 31 & 281 & 58 & 11 & 16 & 152 & 21 & 11 \\
\hline Energy & 3 & 19 & 3 & 3 & 0 & 2 & 0 & 0 \\
\hline High Tech & 19 & 148 & 32 & 4 & 3 & 43 & 2 & 1 \\
\hline Telecom & 11 & 22 & 5 & 1 & 1 & 3 & 1 & 0 \\
\hline Retail & 20 & 184 & 21 & 9 & 5 & 31 & 5 & 1 \\
\hline Health Care & 20 & 112 & 26 & 1 & 5 & 30 & 4 & 4 \\
\hline Other & 41 & 311 & 46 & 14 & 14 & 102 & 16 & 4 \\
\hline Court Location & & & & & & & & \\
\hline Midwest & 38 & 268 & 40 & 13 & 15 & 87 & 12 & 5 \\
\hline Northeast & 33 & 309 & 41 & 10 & 5 & 96 & 10 & 7 \\
\hline West & 49 & 301 & 43 & 6 & 12 & 83 & 9 & 6 \\
\hline South & 67 & 542 & 118 & 29 & 17 & 172 & 27 & 5 \\
\hline
\end{tabular}


NOTE. - This table gives firm characteristics for all U.S. and foreign publicly traded firms sued for antitrust, contract disputes, employment actions, patent infringement, and product liability in U.S. Federal district courts from January 1995 to December 2000. Any lawsuit for which the same firm is sued less than 270 days prior is dropped from the sample. Assets are measured using the book value of Total Assets. Profit is defined as the ratio of Operating Income to Total Assets, expressed in percent. Free Cash Flow is defined as Net Income plus Depreciation less Cash Dividends, expressed as a percent of Total Assets. Leverage is Long Term Debt as a percent of Total Assets. The Market to Book Ratio is the market value of assets (book value of assets less the book value of equity plus the market value of equity) divided by Total Assets. U.S. data comes from Standard and Poor's Compustat database; foreign data comes from Thomson Financial's Worldscope database. P-Values for tests of mean differences account for unequal variances by to the Satterthwaite method; the sign rank test provides p-values for tests of median differences. Significance at the $10 \%, 5 \%$, and $1 \%$ levels are denoted by *,** and $* * *$ respectively. 
Table 2

Determinants of Abnormal Share Price Reaction of Corporate Defendants at the Announcement of U.S. Federal Lawsuits

\begin{tabular}{|c|c|c|c|c|}
\hline & 1 & 2 & 3 & 4 \\
\hline \multicolumn{5}{|c|}{ Panel A: Dependent Variable is Abnormal Return $(-1,1)$} \\
\hline Intercept & $-0.35 *$ & -0.229 & -0.263 & -0.199 \\
\hline U.S. & $0.402 * *$ & $0.405 * *$ & 0.317 & 0.274 \\
\hline Assets & & & & 0.022 \\
\hline Profit & & & & 0.032 \\
\hline Leverage & & & & 0.023 \\
\hline Contract & 0.415 & 0.386 & 0.535 & 0.547 \\
\hline Antitrust & $-0.594 * *$ & $-0.595 * *$ & $-0.657 * *$ & $-0.72 * *$ \\
\hline Employee & 0.246 & 0.245 & 0.208 & 0.216 \\
\hline Patent & $-0.329 *$ & $-0.36 *$ & $-0.395 *$ & -0.356 \\
\hline Year & No & Yes & Yes & Yes \\
\hline Industry & No & No & Yes & Yes \\
\hline Observations & 3,076 & 3,076 & 2,656 & 2,590 \\
\hline \multicolumn{5}{|c|}{ Panel B: Dependent Variable is Abnormal Return $(-1,3)$} \\
\hline Intercept & $-0.682 * * *$ & -0.501 & -0.503 & -0.512 \\
\hline U.S. & $0.659 * * *$ & $0.668 * * *$ & $0.566 * *$ & $0.513 *$ \\
\hline Assets & & & & 0.087 \\
\hline Profit & & & & 0.367 \\
\hline Leverage & & & & $0.031^{*}$ \\
\hline Contract & 0.401 & 0.381 & 0.347 & 0.45 \\
\hline Antitrust & -0.386 & -0.379 & -0.443 & -0.538 \\
\hline Employee & 0.474 & 0.423 & 0.497 & $0.61^{*}$ \\
\hline Patent & -0.246 & -0.271 & -0.344 & -0.283 \\
\hline Year & No & Yes & Yes & Yes \\
\hline Industry & No & No & Yes & Yes \\
\hline Observation & 3,068 & 3,068 & 2,648 & 2,582 \\
\hline
\end{tabular}

Panel C: Sample Selection Model

2a: Dependent Variable is 1 if $\quad 2 b$ : Dependent Variable is the firm is sued and 0 otherwise Abnormal Return $(-1,3)$

\begin{tabular}{lcc} 
Intercept & $-1.808^{* * *}$ & -0.578 \\
US & $-0.178^{* * *}$ & $0.784^{* *}$ \\
Assets & $0.213^{* * *}$ & 0.054 \\
Profit & $0.383^{* * *}$ & 0.079 \\
Leverage & 0.002 & $0.037 * *$ \\
Contract & & 0.133 \\
Antitrust & & -0.373 \\
Employee & & 0.316 \\
Patent & & -0.275 \\
\hline Inverse Mill's ratio & Yes & 0.004 \\
\hline Year & Yes & Yes \\
Industry & & No \\
\hline
\end{tabular}


NOTE. - Lawsuits involving antitrust, contract disputes, employment actions, patent infringement, and product liability are included in the sample. Any lawsuit for which the same firm is sued less than 270 days prior is dropped from the sample. The event date is the date that litigation is filed in a U.S. Federal district court. Abnormal returns are based on the home market stock. Abnormal returns are estimated using a home-market model, and are weighted by prediction errors. Assets are measured as the Book Value of Total Assets. Profit is defined as Operating Income as a percent of Total Assets. Leverage is Long Term Debt as a percent of Total Assets. Industry is defined according to the FamaFrench 10 industry portfolios. Contract, Antitrust, Employee and Patent are dummy variables equal to one if the case is classified as a contract, antitrust, employee, or patent lawsuit. US is a dummy variable equal to one if the defendant is a U.S. corporation. Rho provides a significance test of the sample selection model. P-values are calculated using White (1980) standard errors in Panels A and B, and from the Product of scores of the likelihood function for Panel C. Significance at the 10\%, 5\%, and $1 \%$ levels are denoted by $* * *$ and *** respectively. 
Table 3

Determinants of Abnormal Share Price Reaction of Corporate Defendants at the Announcement of U.S. Federal Lawsuits: The Effect of Court Location

Panel A: OLS Regression

Dependent Variable: Abnormal Return (-1,3) Abnormal Return (-1,3)

Independent Variables

Midwest

0.776

0.658

Northeast

$-1.056$

$-1.228^{*}$

West

0.242

0.063

South

$-0.659$

$-0.816$

Midwest*US

$-0.945 *$

$-0.98 *$

Northeast*US

$1.298 *$

$1.261^{*}$

West*US

0.384

0.369

South*US

$0.915 * *$

$0.852 * *$

Assets

0.072

0.084

Profit

0.355

0.458

Leverage

0.032*

0.031 *

Contract

0.346

0.456

Antitrust

$-0.596 *$

$-0.606 *$

Employee

0.598*

0.584*

Patent

$-0.356$

Year

Yes

$-0.395$

Industry

Observations

No

Yes

2,582

Yes

Panel B: Sample Selection Model

2a: Dependent Variable 2b: Dependent Variable is is 1 if the firm is sued is Abnormal Return and 0 otherwise $(-1,3)$

Independent Variables

Intercept

$-1.808 * * *$

US

$-0.178 * * *$

Midwest

0.845

Northeast

$-1.311$

West

0.093

South

$-1.023$

Midwest*US

$-1.148 *$

Northeast*US

$1.576 * *$

West*US

0.776

South*US

$1.292 * * *$

Assets

$0.213^{* * *}$

0.047

Profit

$0.383 * * *$

0.223

Leverage

0.002

$0.038 * *$

Contract

0.115

Antitrust

$-0.53$

Employee

0.226 


\begin{tabular}{lcc} 
Patent & & $-0.472^{*}$ \\
\hline Inverse Mill's ratio & 0.005 \\
\hline Observations & 91,931 & 91,931 \\
Year & Yes & Yes \\
Industry & Yes & No \\
\hline Observations & 92,148 & 92,148 \\
\hline
\end{tabular}

NOTE. - In Panel A, we use OLS regression to examine price impact of litigation filings for U.S. and foreign firms sued between January 1995 and December 2000 controlling for defendant characteristics. In Panel B, we use a sample selection model to adjust for different rates of lawsuits between U.S. and foreign firms. Lawsuits involving antitrust, contract disputes, employment actions, patent infringement, and product liability are included in the sample. Any lawsuit for which the same firm is sued less than 270 days prior is dropped from the sample. The event date is the date that litigation is filed in a U.S. Federal district court. Abnormal returns are estimated using a home-market model, and are weighted by prediction errors. The dependent variable is the total abnormal return from one day prior to the filing of a lawsuit to three days after the filing of a lawsuit. Assets is the Book Value of Total Assets. Profit is defined as Operating Income as a percent of Total Assets. Leverage is defined as the ratio of Long-Term Debt to Total Assets. Industry is defined according to the Fama-French 10 industry portfolios. South is a dummy variable equal to one if the court is located in the south. West is a dummy variable equal to one if the court is located in the west. Northeast is a dummy variable equal to one if the court is located in the northeast. Midwest is a dummy variable equal to one if the court is located in the Midwest. Contract, Antitrust, Employee, and Patent are dummy variables equal to one if the case is classified as a contract, antitrust, employee, or patent lawsuit. US is a dummy variable equal to one if the defendant is a U.S. corporation. Rho provides a significance test of the sample selection model. P-values are calculated using White (1980) standard errors in Panel A, and from the Product of scores of the likelihood function for Panel B. Significance levels of $10 \%, 5 \%$, and $1 \%$ are denoted by $*$, ** and ${ }^{* * *}$ respectively. 
Table 4

Determinants of Outcomes of U.S. Federal Lawsuits of U.S. and Foreign Corporate Defendants Panel A: Dependent Variable is 1 if Lawsuit; 0 otherwise

\begin{tabular}{lcc}
\hline Independent Variables & $(1)$ & $(2)$ \\
\hline Intercept & $-2.654^{* * *}$ & $-2.654^{* * *}$ \\
US & $-1.14^{* * *}$ & $-1.14^{* * *}$ \\
Assets & $0.484^{* * *}$ & $0.484^{* * *}$ \\
Profit & $1.016^{* * *}$ & $1.016^{* * *}$ \\
Leverage & $0.008^{* *}$ & $0.008^{* *}$ \\
\hline
\end{tabular}

Panel B: Dependent Variable is 1 if, Given Lawsuit, Case is Dismissed; 0 otherwise

\begin{tabular}{lcc}
\hline Independent Variables & $(1)$ & $(2)$ \\
\hline Intercept & $-2.244^{* * *}$ & $-3.271^{* * *}$ \\
US & 0.254 & 0.033 \\
Inverse Mill's ratio & -0.127 & 1.142 \\
Assets & & $0.127^{* * *}$ \\
Profit & & 0.894 \\
Leverage & & -0.402 \\
Contract & $0.578^{*}$ & $0.609^{*}$ \\
Antitrust & $0.978^{* * *}$ & $0.887^{* * *}$ \\
Employee & -0.198 & -0.194 \\
Patent & 0.185 & 0.247 \\
\hline Panel C: Depen
\end{tabular}

Panel C: Dependent Variable is 1 if, Given No Dismissal, Case is Settled; 0 otherwise

\begin{tabular}{lcc}
\hline Independent Variables & $(1)$ & $(2)$ \\
\hline Intercept & 0.062 & -0.032 \\
US & 0.499 & 0.553 \\
$\mathrm{p}(\text { win })^{*}(1-\mathrm{p}($ win $))$ & $7.815^{*}$ & $8.291^{*}$ \\
$\mathrm{p}($ win)*(1-p(win) $) *(\mathrm{US})$ & -2.597 & -2.787 \\
\hline Panel D: Dependent Variable is 1 if, Given No Settlement, Defendant Wins; 0 otherwise \\
\hline Independent Variables & $(1)$ & $(2)$ \\
\hline Intercept & 1.131 & 0.691 \\
US & $0.71^{*}$ & $0.699^{*}$ \\
Assets & & 0.202 \\
Profit & & 0.042 \\
Leverage & & 0.601 \\
Inverse Mill's ratio & -0.394 & -0.455 \\
Contract & -1.071 & -1.027 \\
Antitrust & 0.712 & 0.693 \\
Employee & $-1.13^{* *}$ & $-1.122^{* *}$ \\
Patent & $-0.745^{* *}$ & $-0.704^{* *}$ \\
\hline Year Fixed Effects & Yes & Yes \\
\hline Observations & 91,931 & 91,931 \\
\hline
\end{tabular}




\begin{tabular}{lcc}
\hline Likelihood Tests & $\begin{array}{c}\text { Value of Log- } \\
\text { Likelihood Function }\end{array}$ & $\begin{array}{c}\text { P-value for Likelihood } \\
\text { Ratio Test Against } \\
\text { Model 1 }\end{array}$ \\
\hline Likelihood Model 1 & -993.82 & \\
Likelihood Model 2 & -992.92 & 0.617 \\
No U.S. Dummy in Win Equation & -995.86 & $0.043^{* *}$ \\
\hline
\end{tabular}

NOTE. - We use a sequential logit model, based on Perloff, Rubinfeld, and Ruud (1996), to examine the outcome rates for U.S. and foreign firms sued between January 1995 and December 2000 controlling for defendant characteristics. Lawsuits involving antitrust, contract disputes, employment actions, patent infringement, and product liability are included in the sample. Any lawsuit for which the same firm is sued less than 270 days prior is dropped from the sample. Assets is the Book Value of Total Assets. Profit is defined as Operating Income as a percent of Total Assets. Leverage is defined as the ratio of long-term debt to total assets. Industry is defined according to the Fama-French 10 industry portfolios. Contract, Antitrust, Employee, and Patent are dummy variables equal to one if the case is classified as a contract, antitrust, employee, or patent lawsuit. US is a dummy variable equal to one if the defendant is a U.S. corporation. $\mathrm{P}$ (win) is the probability of a defendant win predicted by the model. $\mathrm{P}($ win $) *(1-\mathrm{P}($ win $))$ is the variance of the probability of a defendant win. Mill's Ratio is the ratio of the normal pdf to the normal cdf, evaluated for each lawsuit using the probability of lawsuit equation estimates. The likelihood ratio is $2 *(\log$ likelihood function value (full) - log likelihood function value (restricted)). This statistic is chi-square with degrees of freedom equal to the number of restrictions. Significance levels of $10 \%, 5 \%$, and $1 \%$ are denoted by $*, * *$ and $* * *$ respectively. 
Table 5

Determinants of Outcomes of U.S. Federal Lawsuits of U.S. and Foreign Corporate Defendants: The Effect of Court Location

\begin{tabular}{lcc}
\hline \multicolumn{4}{l}{ Panel A: Dependent Variable is 1 if Lawsuit; 0 otherwise } \\
\hline Independent Variables & $(1)$ & $(2)$ \\
\hline Intercept & $-2.654^{* * *}$ & $-2.654^{* * *}$ \\
US & $-1.14^{* * *}$ & $-1.14^{* * *}$ \\
Assets & $0.484^{* * *}$ & $0.484^{* * *}$ \\
Profit & $1.016^{* * *}$ & $1.016^{* * *}$ \\
Leverage & $0.008^{* *}$ & $0.008^{* *}$
\end{tabular}

Panel B: Dependent Variable is 1 if, Given Lawsuit, Case is Dismissed; 0 otherwise

\begin{tabular}{lcc}
\hline Independent Variables & $(1)$ & $(2)$ \\
\hline Midwest & $-1.792^{* * *}$ & $-2.782^{* * *}$ \\
Northeast & $-3.018^{* * *}$ & $-4.039^{* * *}$ \\
West & $-2.353^{* * *}$ & $-3.336^{* * *}$ \\
South & $-2.189 * * *$ & $-3.222^{* * *}$ \\
Midwest*US & -0.173 & -0.413 \\
Northeast*US & 0.809 & 0.59 \\
West*US & 0.535 & 0.286 \\
South*US & 0.131 & -0.065 \\
Inverse Mill's ratio & -0.05 & $1.198^{*}$ \\
Assets & & $0.126 * * *$ \\
Profit & & 0.954 \\
Leverage & & -0.425 \\
Contract & $0.563 *$ & $0.592 *$ \\
Antitrust & $0.959 * * *$ & $0.869 * * *$ \\
Employee & -0.215 & -0.209 \\
Patent & 0.121 & 0.184 \\
\hline
\end{tabular}

Panel C: Dependent Variable is 1 if, Given No Dismissal, Case is Settled; 0 otherwise

\begin{tabular}{lcc}
\hline Independent Variables & $(1)$ & $(2)$ \\
\hline Midwest & $-2.459^{* *}$ & $-2.422^{* *}$ \\
Northeast & $-2.62^{* *}$ & $-2.619^{* *}$ \\
West & $-2.576^{* * *}$ & $-2.576^{* *}$ \\
South & -0.217 & -0.285 \\
Midwest*US & 2.289 & 2.206 \\
Northeast*US & $3.017^{* *}$ & $2.99 * *$ \\
West*US & $3.157^{* *}$ & $3.106^{* *}$ \\
South*US & -0.351 & -0.335 \\
p(win)*(1-p(win) $)$ & $18.121^{* * *}$ & $18.068^{* * *}$ \\
p(win)*(1-p(win) $) *(U S)$ & -8.754 & -8.391 \\
\hline
\end{tabular}




\begin{tabular}{lcc}
\hline \multicolumn{3}{l}{ Panel D: Dependent Variable is 1 if, Given No Settlement, Defendant Wins; 0 } \\
otherwise & \multicolumn{1}{l}{$(1)$} & $(2)$ \\
\hline Independent Variables & 0.565 & 0.586 \\
Midwest & 0.254 & 0.244 \\
Northeast & 0.39 & 0.374 \\
West & $2.217^{* * *}$ & $2.131^{* * *}$ \\
South & 0.833 & 0.815 \\
Midwest*US & $1.743^{* *}$ & $1.757^{* *}$ \\
Northeast*US & $1.898^{* * *}$ & $1.877^{* * *}$ \\
West*US & -0.702 & -0.63 \\
South*US & -0.335 & -0.254 \\
Inverse Mill's ratio & & 0.009 \\
Assets & & 0.238 \\
Profit & -0.209 & -0.328 \\
Leverage & $0.598^{* * *}$ & -0.208 \\
Contract & $-0.743^{* * *}$ & $0.573^{* *}$ \\
Antitrust & $-0.394^{* * *}$ & $-0.733^{* * *}$ \\
Employee & $-0.384^{* * *}$ \\
Patent & Yes & Yes \\
\hline Year Fixed Effects & 91,931 & 91,931 \\
\hline Observations & Value of Log- \\
\hline Likelihood Tests & P-value for \\
& Likelihood Function Likelihood Ratio Test \\
\hline Likelihood Model 1 & Against Model 1 \\
Likelihood Model 2 & -979.59 & \\
No U.S. Dummies in Win Equation & -979.05 & 0.784 \\
U.S. Dummy is the Same for All Regions in & -986.96 & $0.005^{* * *}$ \\
Win Equation & -985.04 & $0.014^{* *}$ \\
\hline
\end{tabular}

NOTE. - We use a sequential logit model, based on Perloff, Rubinfeld, and Ruud (1996), to examine the outcome rates for U.S. and foreign firms sued between January 1995 and December 2000 controlling for defendant characteristics. Lawsuits involving antitrust, contract disputes, employment actions, patent infringement, and product liability are included in the sample. Any lawsuit for which the same firm is sued less than 270 days prior is dropped from the sample. Assets is the Book Value of Total Assets. Profit is defined as Operating Income as a percent of Total Assets. Leverage is defined as the ratio of long-term debt to total assets. Industry is defined according to the Fama-French 10 industry portfolios. South is a dummy variable equal to one if the court is located in the south. West is a dummy variable equal to one if the court is located in the west. Northeast is a dummy variable equal to one if the court is located in the northeast. Midwest is a dummy variable equal to one if the court is located in the Midwest. Contract, Antitrust, Employee, and Patent are dummy variables equal to one if the case is classified as a contract, antitrust, employee, or patent lawsuit. US is a dummy variable equal to one if the defendant is a U.S. corporation. $\mathrm{P}($ win) is the probability of a defendant win predicted by the model. $\mathrm{P}($ win $) *(1-\mathrm{P}($ win) $)$ is the variance of the probability of a defendant win. Mill's Ratio is the ratio of the normal pdf to the normal cdf, evaluated for each lawsuit using the probability of lawsuit equation estimates. The likelihood ratio is $2 *$ (log likelihood function value (full) - log likelihood function value (restricted)). This statistic is chi-square with degrees of freedom equal to the number of restrictions. Significance levels of $10 \%, 5 \%$, and $1 \%$ are denoted by ${ }^{*},{ }^{* *}$ and ${ }^{* * *}$ respectively. 
Table 6

U.S. and Non-U.S. Corporate Defendant Abnormal Returns and Win Percentages: By Plaintiff Type

\begin{tabular}{|c|c|c|c|c|}
\hline \multicolumn{5}{|c|}{ Panel A: Diversity of Residence Jurisdiction } \\
\hline \multicolumn{2}{|l|}{ Defendant } & $\begin{array}{l}\text { U.S. Individual } \\
\text { Plaintiff }\end{array}$ & $\begin{array}{c}\text { Foreign } \\
\text { Individual } \\
\text { Plaintiff } \\
\end{array}$ & $\begin{array}{c}\text { Corporate } \\
\text { Plaintiff }\end{array}$ \\
\hline \multirow[t]{4}{*}{ U.S. Defendant: } & $\mathrm{N}$ & 822 & 11 & 59 \\
\hline & Mean Return (\%) & -0.0533 & 0.5903 & $1.1452 * *$ \\
\hline & Median Return (\%) & $-0.2759 * *$ & -0.0238 & 0.6438 \\
\hline & Win \% (N: Wins + Losses) & $86.79(106)$ & $100(1)$ & $55.56(9)$ \\
\hline \multicolumn{2}{|c|}{ Foreign Defendant: $\mathrm{N}$} & 298 & 3 & 14 \\
\hline & Mean Return (\%) & -0.2205 & 2.1620 & -0.7429 \\
\hline & Median Return (\%) & -0.4149 & 4.3285 & -1.6241 \\
\hline & Win \% (N: Wins + Losses) & $85.00(40)$ & NA & $100(2)$ \\
\hline \multirow{3}{*}{\multicolumn{2}{|c|}{$\begin{array}{l}\text { U.S. Mean Ret. = Foreign Mean Ret.: P-value } \\
\text { U.S. Med. Ret. = Foreign Med. Ret.: P-value } \\
\text { U.S. Win \% = Foreign Win \%: P-Value }\end{array}$}} & 0.5460 & 0.6792 & 0.0952 \\
\hline & & 0.9323 & 0.5334 & 0.0576 \\
\hline & & 0.7788 & NA & 0.1535 \\
\hline \multicolumn{5}{|l|}{ Panel B: Others } \\
\hline \multicolumn{2}{|l|}{ Defendant } & All & & \\
\hline \multirow[t]{4}{*}{ U.S. Defendant: } & $\mathrm{N}$ & 1,263 & & \\
\hline & Mean Return (\%) & -0.0284 & & \\
\hline & Median Return (\%) & -0.1086 & & \\
\hline & Win \% (N: Wins + Losses) & $76.62(154)$ & & \\
\hline \multicolumn{2}{|c|}{ Foreign Defendant: $\mathrm{N}$} & 356 & & \\
\hline & Mean Return (\%) & $-0.7683 * * *$ & & \\
\hline & Median Return (\%) & $-0.5692 * * *$ & & \\
\hline & Win \% (N: Wins + Losses) & $47.06(34)$ & & \\
\hline \multirow{3}{*}{\multicolumn{2}{|c|}{$\begin{array}{l}\text { U.S. Mean Ret. = Foreign Mean Ret.: P-value } \\
\text { U.S. Med. Ret. = Foreign Med. Ret.: P-value } \\
\text { U.S. Win \% = Foreign Win \%: P-Value }\end{array}$}} & 0.0178 & & \\
\hline & & 0.0334 & & \\
\hline & & 0.0006 & & \\
\hline
\end{tabular}

NoTE. - This table gives initial returns and win/loss percentages for U.S. and foreign publicly traded firms sued in U.S. Federal district courts from January 1995 to December 2000. Lawsuits involving antitrust, contract disputes, employment actions, patent infringement, and product liability are included in the sample. Any lawsuit for which the same firm is sued less than 270 days prior is dropped from the sample. When the parties to a lawsuit reside in two different states or countries, the Federal District Court has jurisdiction because of diversity of residence. ICPSR provides limited residence information for the two parties in these diversity of residence cases. Panel A provides results for diversity of residence cases, all other cases are presented in Panel B. P-Values for tests of mean differences are adjusted for unequal variances. Significance at the $10 \%, 5 \%$, and $1 \%$ levels are denoted by $*$, ** and *** respectively. 
Table 7 Foreign ADR vs Foreign Non-ADR Corporate Defendants in U.S. Federal Lawsuits:
Summary Statistics

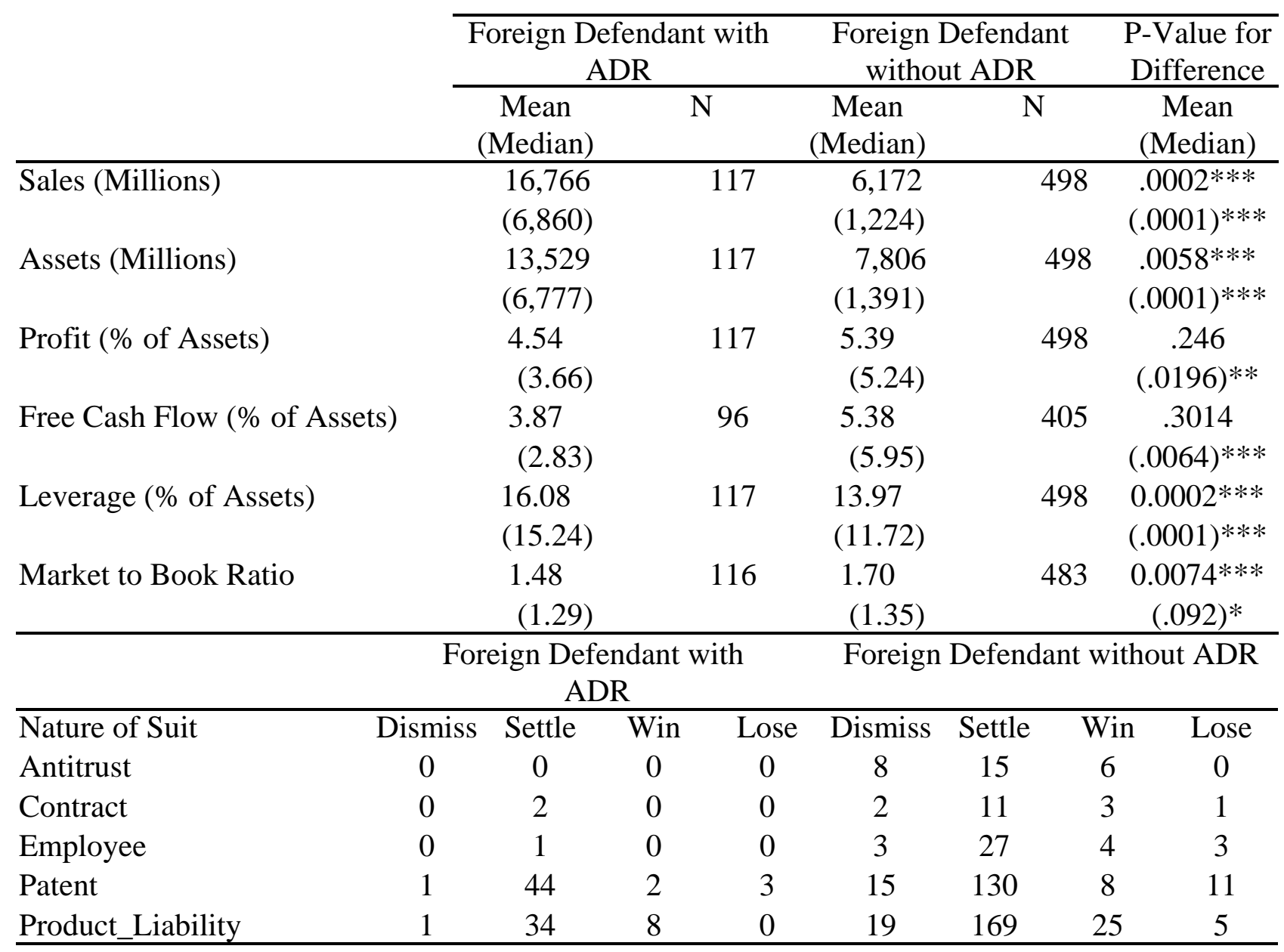

NoTE. -This table gives firm characteristics for all foreign publicly traded firms sued in U.S. Federal district courts from January 1995 to December 2000. ADR firms are any firms for which the Bank of New York has an ADR listed as Level I, II, III, or Rule 144a. Lawsuits involving antitrust, contract disputes, employment actions, patent infringement, and product liability are included in the sample. Any lawsuit for which the same firm is sued less than 270 days prior is dropped from the sample. Assets is the Book Value of Total Assets. Profit is defined as the ratio of Operating Income to Total Assets, expressed in percent. Free Cash Flow is defined as Net Income plus Depreciation less Cash Dividends, expressed as a percent of Total Assets. Leverage is Long Term Debt as a Percent of Assets. The Market to Book Ratio is the market value of assets (book value of assets less the book value of equity plus the market value of equity) divided by Total Assets. U.S. data comes from Standard and Poor's Compustat database, foreign data from Thomson Financial's Worldscope database. P-Values for tests of mean differences account for unequal variances by to the Satterthwaite method; the sign rank test provides p-values for tests of median differences. Significance at the $10 \%, 5 \%$, and $1 \%$ levels are denoted by *,** and *** respectively. 


\section{Table 8}

Determinants of Abnormal Share Price Reaction of Foreign Corporate Defendants at the Announcement of U.S. Federal Lawsuits

\begin{tabular}{lcc}
\hline & 1 & 2 \\
\hline \multicolumn{2}{l}{ Dependent Variable: Abnormal Returns (-1,3) } \\
\hline Independent Variables \\
Midwest \\
Northeast & $1.491^{*}$ & \\
West & 0.508 & 0.909 \\
South & 1.06 & -1.257 \\
Midwest*ADR & 0.293 & 0.564 \\
Northeast*ADR & 0.769 & -0.232 \\
West*ADR & 1.143 & 0.867 \\
South*ADR & 0.15 & 1.597 \\
\hline Assets & -0.377 & 0.0164 \\
Profit & 0.122 & -0.408 \\
Leverage & -0.474 & 0.11 \\
Contract & 0.033 & -0.4 \\
\hline Antitrust & -1.31 & 0.028 \\
Employee & 1.128 & -1.197 \\
Patent & 0.79 & 1.195 \\
\hline Year & -0.533 & 1.221 \\
Industry & Yes & -0.47 \\
Observations & No & Yes \\
\hline
\end{tabular}

NoTE. -We use an OLS regression to examine price impact of litigation filings for U.S. and foreign firms sued between January 1995 and December 2000 controlling for defendant characteristics. Lawsuits involving Antitrust, Contract disputes, Employment actions, Patent infringement, and Product liability are included in the sample. Any lawsuit for which the same firm is sued less than 270 days prior is dropped from the sample. The event date is the date that litigation is filed in a U.S. Federal district court. Abnormal returns are estimated using a home-market model, and are weighted by prediction errors. The dependent variable is the total abnormal return from one day prior to the filing of a lawsuit to three days after the filing of a lawsuit. Assets is the Book Value of Total Assets. Profit is defined as Operating Income as a percent of Total Assets. Leverage is defined as the ratio of longterm debt to total assets. Industry is defined according to the Fama-French 10 industry portfolios. South is a dummy variable equal to one if the court is located in the south. West is a dummy variable equal to one if the court is located in the west; Northeast is a dummy variable equal to one if the court is located in the northeast. Midwest is a dummy variable equal to one if the court is located in the Midwest. Contract, Employee, and Patent are dummy variables equal to one if the case is classified as a Contract, employee, or Patent lawsuit. ADR is a dummy variable equal to one if the defendant has a Level 1, 2, 3, or Rule 144A ADR included in the Bank of New York's ADR list. P-values are calculated using White (1980) standard errors. Significance levels of 10\%, 5\%, and 1\% are denoted by $*$, ** and *** respectively. 
Table 9

Determinants of Outcomes of U.S. Federal Lawsuits of Foreign Corporate Defendants

\begin{tabular}{|c|c|c|}
\hline \multicolumn{3}{|c|}{ Panel A: Dependent Variable is 1 if, Given Lawsuit, Case is Dismissed; 0 otherwise } \\
\hline Independent Variables & (1) & $(2)$ \\
\hline Midwest & $-1.767 * * *$ & $-2.075 * * *$ \\
\hline Northeast & -3.055 & -3.491 \\
\hline West & -1.966 & -2.555 \\
\hline South & -2.321 & -2.567 \\
\hline Midwest*ADR & -0.755 & -1.041 \\
\hline Northeast*ADR & -12.053 & -12.175 \\
\hline West*ADR & -1.375 & -13.407 \\
\hline South*ADR & -0.792 & -1.18 \\
\hline \multicolumn{3}{|c|}{ Panel B: Dependent Variable is 1 if, Given No Dismissal, Case is Settled; 0 otherwise } \\
\hline Independent Variables & $(1)$ & $(2)$ \\
\hline Midwest & $1.561^{*}$ & $2.576 * * *$ \\
\hline Northeast & 1.154 & $2.332 * * *$ \\
\hline West & 1.401 & $2.479 * * *$ \\
\hline South & $1.607 * *$ & $2.335^{* * *}$ \\
\hline Midwest*ADR & -0.182 & 0.299 \\
\hline Northeast*ADR & 0.603 & 0.776 \\
\hline West*ADR & -0.015 & -0.201 \\
\hline South*ADR & 0.239 & 0.6 \\
\hline $\mathrm{p}$ (win)*(1-p(win)) & 4.812 & $-7.104 * * *$ \\
\hline \multicolumn{3}{|c|}{ Panel C: Dependent Variable is 1 if, Given No Settlement, Defendant Wins; 0 otherwise } \\
\hline Independent Variables & $(1)$ & $(2)$ \\
\hline Midwest & $2.912 * *$ & $5.507 *$ \\
\hline Northeast & 1.4 & 1.688 \\
\hline West & $2.333 *$ & $4.971 *$ \\
\hline South & $3.165 * *$ & 15.02 \\
\hline Midwest*ADR & -1.312 & -9.52 \\
\hline Northeast*ADR & 0.238 & -2.115 \\
\hline \multicolumn{3}{|l|}{ West*ADR } \\
\hline South*ADR & 0.234 & 1.535 \\
\hline Assets & & 33.702 \\
\hline Profit & & 7.019 \\
\hline Leverage & & -16.207 \\
\hline Contract & -0.141 & \\
\hline \multicolumn{3}{|l|}{ Antitrust } \\
\hline Employee & -1.069 & -9.201 \\
\hline Patent & $-2.103 * * *$ & -4.698 \\
\hline Year Dummies & Yes & Yes \\
\hline Observations & 519 & 441 \\
\hline
\end{tabular}

NoTE. -We use a sequential logit model, based on Perloff, Rubinfeld, and Ruud (1996), to examine the outcome rates for U.S. and foreign firms sued between January 1995 and December 2000 controlling 
for defendant characteristics. Lawsuits involving antitrust, contract disputes, employment actions, patent infringement, and product liability are included in the sample. Any lawsuit for which the same firm is sued less than 270 days prior is dropped from the sample. Assets is the Book Value of Total Assets. Profit is defined as Operating Income as a percent of Total Assets. Leverage is defined as the ratio of long-term debt to total assets. Industry is defined according to the Fama-French 10 industry portfolios. South is a dummy variable equal to one if the court is located in the south. West is a dummy variable equal to one if the court is located in the west. Northeast is a dummy variable equal to one if the court is located in the northeast. Midwest is a dummy variable equal to one if the court is located in the Midwest. Contract, Antitrust, Employee, and Patent are dummy variables equal to one if the case is classified as a contract, antitrust, employee, or patent lawsuit. ADR is a dummy variable equal to one if the defendant has a Level 1, 2, 3, or Rule 144A ADR included in the Bank of New York's ADR list. $\mathrm{P}($ win) is the probability of a defendant win predicted by the model. $\mathrm{P}($ win $) *(1-$ $\mathrm{P}($ win) $)$ is the variance of the probability of a defendant win. Significance levels of $10 \%, 5 \%$, and $1 \%$ are denoted by $*, * *$ and $* * *$ respectively. 
Table 10

Determinants of Outcomes of U.S. Federal Lawsuits of U.S. and Foreign Corporate Defendants: Judge vs Jury Trials

\begin{tabular}{lcc}
\hline \multicolumn{2}{l}{ Panel A: Dependent Variable is 1 if, Given No Settlement, Defendant Wins; 0 otherwise } \\
\hline Independent Variables & $(1)$ & $(2)$ \\
Foreign \& Judge & 0.713 & 0.785 \\
Foreign \& Jury & -0.048 & 0.471 \\
US \& Judge & $1.685^{* * *}$ & $1.617^{* * *}$ \\
US \& Jury & -0.264 & -0.29 \\
Midwest & -0.162 & 0.185 \\
Northeast & -0.267 & 0.379 \\
West & 0.122 & 0.511 \\
Assets & & -0.004 \\
Profit & & 1.341 \\
Leverage & -0.725 & -0.132 \\
\hline Contract & $1.052^{*}$ & -0.696 \\
Antitrust & -0.681 & 0.783 \\
Employee & $-0.55^{*}$ & -0.573 \\
Patent & & -0.397 \\
\hline Fixed Effects & Yes & \\
Industry & Yes & No \\
Year & & Yes \\
\hline Panel B: P-values for Tests of Equality & 0.2287 & \\
\hline Foreign \& Judge = Foreign and Jury & 0.0001 & 0.6485 \\
US \& Judge = US \& Jury & 0.0162 & 0.0001 \\
Foreign \& Judge = US \& Judge & 0.7371 & 0.0679 \\
Foreign \& Jury = US \& Jury & 265 & 0.2732 \\
Defendant Win & 72 & 257 \\
Plaintiff Win & & 65 \\
\hline
\end{tabular}

NoTE. - This table presents coefficient estimates for the logit model specifications for the probability that a firm wins a lawsuit. Lawsuits involving antitrust, contract disputes, employment actions, patent infringement, and product liability are included in the sample. Any lawsuit for which the same firm is sued less than 270 days prior is dropped from the sample. In order to be included, a lawsuit must conclude with a win or loss. Wins are defined as dismissals, summary judgements in favor of the defendant, bench trials in favor of the defendant, or jury trails in favor of the defendant. US \& Jury takes a value of 1 if the case is heard by a jury and the firm is a U.S. firm. US \& Judge takes a value of 1 if the case is decided by a judge and the firm is a U.S. firm. Foreign \& Jury takes a value of 1 if the case is heard by a jury and the firm is a foreign defendant firm. Foreign \& Judge takes a value of 1 if the case is decided by a judge and the firm is a foreign defendant firm. Assets is the Book Value of Total Assets. Profit is defined as Operating Income as a percent of Total Assets. Leverage is defined as the ratio of Long-Term Debt to Total Assets. Estimates from models with industry dummy variables and Assets, Profit, and Leverage do not converge. Significance at the $10 \%$, 5\%, and 1\% levels are denoted by $*, * *$ and $* * *$ respectively. 


\section{Abnorm al returns before and after events}

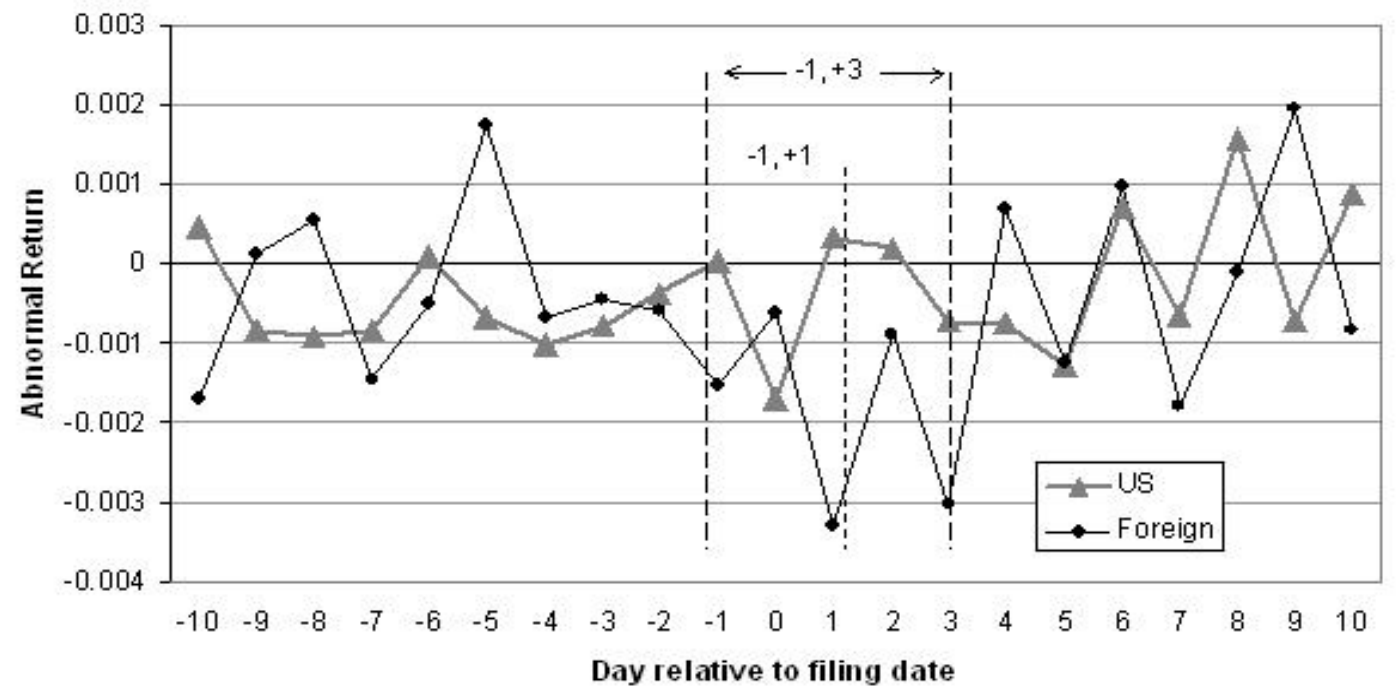

Figure 1.-Average abnormal returns for defendant firms around the filing of litigation (day 0) 

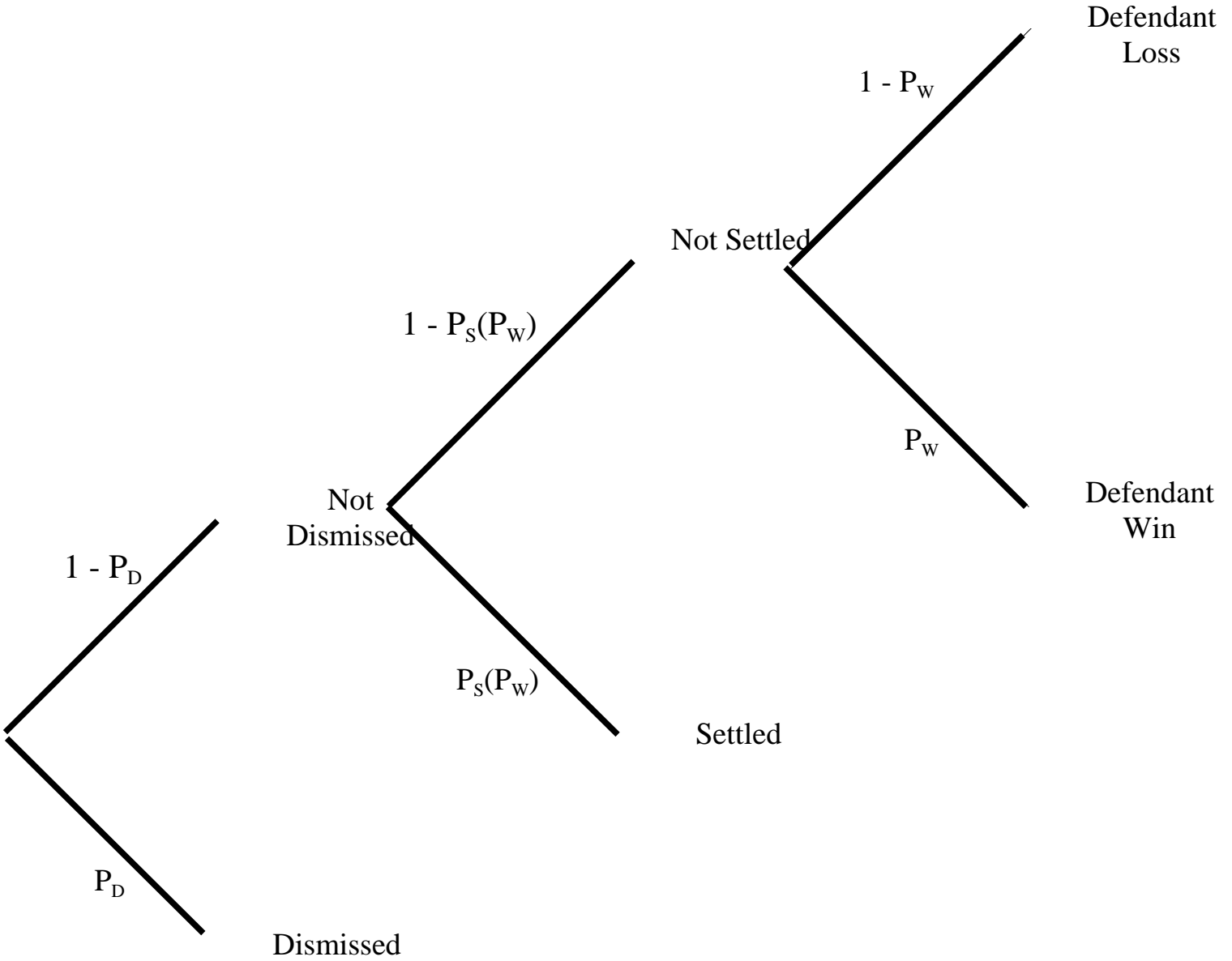

Figure 2. - Possible litigation outcomes. A case is dismissed with probability $\mathrm{P}_{\mathrm{D}}$. If not dismissed, the case is settled with probability $\mathrm{P}_{\mathrm{S}}\left(\mathrm{P}_{\mathrm{W}}\right)$, which depends on the probability of defendant win. If not settled, the defendant wins the case with probability $\mathrm{P}_{\mathrm{w}}$. 